\title{
In-situ observations of young contrails - overview and selected results from the CONCERT campaign
}

\author{
C. Voigt ${ }^{1,2}$, U. Schumann ${ }^{1}$, T. Jurkat ${ }^{1}$, D. Schäuble ${ }^{1,2}$, H. Schlager ${ }^{1}$, A. Petzold ${ }^{1}$, J.-F. Gayet ${ }^{3}$, M. Krämer ${ }^{4}$, \\ J. Schneider ${ }^{5}$, S. Borrmann ${ }^{2,5}$, J. Schmale ${ }^{5}$, P. Jessberger ${ }^{1}$, T. Hamburger ${ }^{1}$, M. Lichtenstern ${ }^{1}$, M. Scheibe ${ }^{1}$, \\ C. Gourbeyre ${ }^{3}$, J. Meyer ${ }^{4}$, M. Kübbeler ${ }^{4}$, W. Frey ${ }^{2}$, H. Kalesse ${ }^{2}$, T. Butler ${ }^{5}$, M. G. Lawrence ${ }^{5}$, F. Holzäpfel ${ }^{1}$, \\ F. Arnold ${ }^{1,6}$, M. Wendisch ${ }^{7}$, A. Döpelheuer ${ }^{8}$, K. Gottschaldt ${ }^{1}$, R. Baumann ${ }^{1}$, M. Zöger ${ }^{9}$, I. Sölch ${ }^{1}$, M. Rautenhaus ${ }^{1}$, \\ and A. Dörnbrack ${ }^{1}$ \\ ${ }^{1}$ Deutsches Zentrum für Luft- und Raumfahrt, Institut für Physik der Atmosphäre, Oberpfaffenhofen, Germany \\ ${ }^{2}$ Institut für Physik der Atmosphäre, Johannes-Gutenberg Universität Mainz, Mainz, Germany \\ ${ }^{3}$ Universite Clermont Ferrand, LaMP, Clermont Ferrand, France \\ ${ }^{4}$ Institut für Stratosphärenforschung, FZ Jülich, Jülich, Germany \\ ${ }^{5}$ Max-Planck-Institut für Chemie, Mainz, Germany \\ ${ }^{6}$ Max-Planck-Institut für Kernphysik, Heidelberg, Germany \\ ${ }^{7}$ Institut für Meteorologie, Universität Leipzig, Germany \\ ${ }^{8}$ Deutsches Zentrum für Luft- und Raumfahrt, Institut für Antriebstechnik, Köln, Germany \\ ${ }^{9}$ Deutsches Zentrum für Luft- und Raumfahrt, Flugabteilung, Oberpfaffenhofen, Germany
}

Received: 20 April 2010 - Published in Atmos. Chem. Phys. Discuss.: 17 May 2010

Revised: 17 August 2010 - Accepted: 3 September 2010 - Published: 30 September 2010

\begin{abstract}
Lineshaped contrails were detected with the research aircraft Falcon during the CONCERT - CONtrail and Cirrus ExpeRimenT - campaign in October/November 2008. The Falcon was equipped with a set of instruments to measure the particle size distribution, shape, extinction and chemical composition as well as trace gas mixing ratios of sulfur dioxide $\left(\mathrm{SO}_{2}\right)$, reactive nitrogen and halogen species $\left(\mathrm{NO}, \mathrm{NO}_{\mathrm{y}}, \mathrm{HNO}_{3}, \mathrm{HONO}, \mathrm{HCl}\right)$, ozone $\left(\mathrm{O}_{3}\right)$ and carbon monoxide (CO). During 12 mission flights over Europe, numerous contrails, cirrus clouds and a volcanic aerosol layer were probed at altitudes between 8.5 and $11.6 \mathrm{~km}$ and at temperatures above $213 \mathrm{~K}$. 22 contrails from 11 different aircraft were observed near and below ice saturation. The observed NO mixing ratios, ice crystal and soot number densities are compared to a process based contrail model. On 19 November 2008 the contrail from a CRJ-2 aircraft was penetrated in $10.1 \mathrm{~km}$ altitude at a temperature of $221 \mathrm{~K}$. The contrail had mean ice crystal number densities of $125 \mathrm{~cm}^{-3}$ with effective radii $r_{\text {eff }}$ of $2.6 \mu \mathrm{m}$. The presence of particles with $r>50 \mu \mathrm{m}$ in the less than 2 min old contrail suggests that natural cirrus crystals were entrained in the contrail. Mean HONO/NO $\left(\mathrm{HONO} / \mathrm{NO}_{\mathrm{y}}\right)$ ratios of $0.037(0.024)$ and the fuel sulfur con-
\end{abstract}

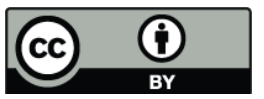

Correspondence to: $\mathrm{C}$. Voigt (christiane.voigt@dlr.de) version efficiency to $\mathrm{H}_{2} \mathrm{SO}_{4}\left(\epsilon_{S \downarrow}\right)$ of $2.9 \%$ observed in the CRJ-2 contrail are in the range of previous measurements in the gaseous aircraft exhaust. On 31 October 2010 aviation NO emissions could have contributed by more than $40 \%$ to the regional scale NO levels in the mid-latitude lowest stratosphere. The CONCERT observations help to better quantify the climate impact from contrails and will be used to investigate the chemical processing of trace gases on contrails.

\section{Introduction}

While aircraft induced cloudiness potentially has the largest aviation impact on climate, the exact magnitude of its contribution to the anthropogenic radiative forcing remains highly uncertain (Lee et al., 2009). Aircraft induced cloudiness plays a role for the climate by reflecting solar radiation and trapping outgoing terrestrial longwave radiation. Latter effect is expected to dominate for contrails and thin cirrus, which results in a net positive radiative forcing (Penner et al., 1999).

Contrails form when the relative humidity in the young exhaust increases due to mixing of the hot and humid exhaust with the colder and less humid ambient air (Schumann, 1996; Kärcher, 1996). When saturation with respect to water is reached, water condenses on soot and sulfate aerosol and

Published by Copernicus Publications on behalf of the European Geosciences Union. 
forms liquid droplets. Thereby the aerosol originates from the combustion process or was entrained in the exhaust with the ambient air (Jensen et al., 1998). When the exhaust further cools down through mixing with ambient air, ice saturation may be reached and ice nucleates in the liquid droplets (Kärcher and Yu, 2009). Hence contrail formation and properties of young contrails may depend on the combustion process and on properties of the contrail-forming aircraft (Schumann, 1996; Schumann et al., 2000; Sussmann and Gierens, 1999). When the ambient air remains supersaturated with respect to ice, the contrail ice crystals can grow by condensation of entrained water vapor (Schröder et al., 2000). Contrail dimensions and contrail coverage increase in ice supersaturated air due to particle sedimentation and contrail spreading in an atmospheric environment with wind shear, while contrail extinction and ice crystal concentrations decrease due to dilution (Freudenthaler et al., 1995).

Observations of the microphysical properties of young contrails are rare. Mean effective radii of contrail ice crystals derived from in situ data show values below $2 \mu \mathrm{m}$ initially (Heymsfield et al., 1998; Baumgardner and Gandrud, 1998), increasing due to condensation to values of up to $5 \mu \mathrm{m}$ at 30 min contrail age (Schröder et al., 2000). Initial ice crystal concentrations larger than $1000 \mathrm{~cm}^{-3}$ have been detected in a few seconds old contrails (Heymsfield et al., 1998) decreasing by dilution to concentrations of less than $100 \mathrm{~cm}^{-3}$ within the first minutes (Poellot et al., 1999; Febvre et al., 2009). In persistent contrails with ages of few hours, ice crystal concentrations of less than $20 \mathrm{~cm}^{-3}$ have been observed (Lawson et al., 1998; Schäuble et al., 2009). Contrail widths of 100-300 $\mathrm{m}$ have been derived from in situ measurements (Poellot et al., 1999) for less than 15 minutes old contrails increasing to $1-3 \mathrm{~km}$ for less than 30 min old contrails (Freudenthaler et al., 1995).

Little is known on chemical contrail properties and the uptake of $\mathrm{HNO}_{3}$ in contrails. Gaseous $\mathrm{HNO}_{3}$ has been detected in aircraft exhaust at cruise (Arnold et al., 1992; Tremmel et al., 1998). High levels of $\mathrm{HNO}_{3}$ are expected in the young aircraft exhaust, which can be rapidly taken up by aircraft aerosol and contrails (Kärcher, 1996). At temperatures below $205 \mathrm{~K}$, the gas phase $\mathrm{HNO}_{3}$ is significantly reduced due to uptake in contrail ice crystals as detected for the contrail of a WB-57 at $14 \mathrm{~km}$ altitude (Popp et al., 2004). Nitric acid in the ice crystals at these temperatures might be present in the form of NAT (Gao et al., 2004; Voigt et al., 2008). Schäuble et al. (2009) show first quantitative measurements of the $\mathrm{HNO}_{3}$ content in contrails. They report enhanced ice phase $\mathrm{HNO}_{3}$ fractions in persistent contrails compared to natural cirrus clouds (Voigt et al., 2006, 2007; Kärcher and Voigt, 2006; Krämer et al., 2008). When the age of the contrail is known, the contrail ice crystals can serve as atmospheric laboratory for the study of the temporal evolution of trace gas uptake in ice crystals (Schäuble et al., 2009; Kärcher et al., 2009b).
Given the sparsity of in-situ measurements of young contrails, measurements of chemical and optical contrail properties are of importance to better quantify their chemical and radiative impact on the atmosphere. Hence we report here on a new set of contrail observations above Europe. The measurements have been performed with the DLR research aircraft Falcon during the CONCERT (CONtrail and Cirrus ExperRimenT) campaign from 22 October to 20 November 2008. The first two weeks of the campaign (CONCERT-CHEMISTRY) were focussed on heterogeneous chemistry on contrails, cirrus and aerosol, while the second part (CONCERT-2-CONTRAIL) concentrated on microphysical and optical contrail properties. During the CONCERT campaign, cirrus clouds were encountered during 10 mission and 2 instrument test flights for almost 2 hours. 22 contrails from 11 different aircraft were sampled in total for 1.7 hours at temperatures from 213 to $229 \mathrm{~K}$ (27 and 28 October and 2, 17, 19 and 20 November 2008). Here we use the contrail observations for model validation. Further, we investigate in detail the microphysical properties from a CRJ-2 contrail and analyze the chemical processing of $\mathrm{SO}_{2}$ and $\mathrm{NO}$ in the engine and the young contrail. Large scale aircraft NO emissions were predicted from global model simulations and measured during two mission flights on 31 October 2008.

In addition, a sulfate aerosol layer was detected in the lowermost stratosphere at altitudes between 8.6 and $11.6 \mathrm{~km}$ (28 and 31 October 2008). The layer most likely originated from the eruption of the Aleutian volcano Mt. Kasatochi on 7/8 August 2008, injecting $1.5 \mathrm{Mt} \mathrm{SO}_{2}$ into the high latitude stratosphere. We discuss the chemical processing of sulfur and halogens species in the aged volcanic plume and derive the e-folding lifetime of $\mathrm{SO}_{2}$ in the northern latitude lowest stratosphere.

\section{Aircraft instrumentation}

During the CONCERT campaign, the DLR research aircraft Falcon was equipped with a set of instruments to detect microphysical particle properties and trace gas composition in the UTLS.

\subsection{The Forward Scattering Spectrometer Probe FSSP300}

Particle size distribution and number density were detected with a forward scattering spectrometer probe (Schröder et al., 2000). The FSSP300 detects light scattered by particles in the diameter range $0.45-17.7 \mu \mathrm{m}$. The particles were grouped into size channels according to T-matrix calculations by Borrmann et al. (2000) assuming aspherical particles with an aspect ratio of 1:2 composed of pure ice with a refractive index of 1.31. Adjustments of the mean channel size were made to account for instrumental manufacturing differences. Further, FSSP channels $8+9,10+11,12+13+14+15,16+17$, 
$18+19,20+21+22+23+24,25+26,29+30$ were grouped to increase the counting statistics particularly in channels with a small channel widths. This data evaluation method proved to achieve best agreement between the FSSP data and the particle scattering phase function detected with the Polar Nephelometer.

\subsection{The 2D-C Probe, the Polar Nephelometer (PN) and the Cloud Particle Imager (CPI)}

The particle size distribution of large particles $(100 \mu \mathrm{m}$ to $1 \mathrm{~mm}$ ) was measured with a 2D-C probe, the particle shape $(2.3 \mu \mathrm{m}$ pixel size) with a cloud particle imager (CPI) and the scattering phase function of cloud particles $(3 \mu \mathrm{m}$ to $1 \mathrm{~mm})$ with a Polar Nephelometer (PN). The method of data processing, the reliability of the instruments and the uncertainties of the derived microphysical and optical parameters have been described in detail by Gayet et al. (2009).

The 2D-C probe provides information on crystal size and shape for the size range 100 to $800 \mu \mathrm{m}$. The method of data processing used in this study has been described in detail by Febvre et al. (2009). The "reconstructed" method using partial images, was considered for the calculations and the sampling surfaces were derived according to Heymsfield and Parrish (1978). In order to improve the statistical significance of low particle concentrations, a 5-second running mean was applied. Irregular ice particles were the most predominant crystals sampled during the CONCERT experiment. Therefore, the bulk parameters were calculated assuming the surface-equivalent diameter relationships (Heymsfield, 1972; Locatelli and Hobbs, 1974). As the sensitivity of the probe to small particles decreases with airspeed (Lawson et al., 2006), particles smaller than about $100 \mu \mathrm{m}$ may not be detectable with the 2D-C at a Falcon airspeed of $200 \mathrm{~m} / \mathrm{s}$.

The CPI records very high resolution $(2.3 \mu \mathrm{m})$ digital images of cloud particles as they pass through the sample tube of the instrument. It casts an image of the particle on a solidstate CCD camera by freezing the motion of the particle using a $25 \mathrm{~ns}$ pulsed, high-power laser diode. Upstream lasers precisely define the depth-of-field so that at least one particle in the image is almost always in the focus. This eliminates out-of-focus sizing errors that have plagued the conventional $2 \mathrm{D}$ imaging probes. The method of data processing leads to derive the particle size distribution, shape and extinction coefficient.

The PN is designed to measure the optical and microphysical parameters of clouds containing either water droplets or ice crystals or a mixture of both over a size range from a few micrometers to about 800 microns diameter. The probe measures the scattering phase function of an ensemble of cloud particles which intersect a collimated laser beam near the focal point of a paraboloidal mirror. The light scattered from polar angles from \pm 3.49 to $\pm 169^{\circ}$ is reflected onto a circular array of 54 photodiodes. The signal processing electronics and computer storage can provide one measurement of the scattering phase function every $10 \mathrm{~ms}$. The optical properties (extinction coefficient, asymmetry factor, backscattering coefficient) are derived from the measured scattering phase functions. The particle size spectra and subsequent derived quantities such bulk and size parameters are retrieved using an inversion technique. The particle phase discrimination (water droplet/ice particles) can be derived from the shape of the scattering phase function.

\subsection{The Cloud Imaging Probe (CIP)}

During the last flight the 2D-C has been exchanged with a Cloud Imaging Probe (CIP), which is a new version of the 2D-C. The CIP measures the size and shape of particles passing through its collimated laser beam, from $125 \mu \mathrm{m}$ to $1600 \mu \mathrm{m}$ with a resolution of $25 \mu \mathrm{m}$. It is capable to detect particle concentrations up to $100 \mathrm{~cm}^{-3}$ at airspeeds up to $200 \mathrm{~m} / \mathrm{s}$. It uses a fast 64 -element photodiode array to generate 2-dimensional images of the particles. The uncertainty in the CIP particle number concentration is mainly determined by the uncertainty in the sample volume of $20 \%$. At low particle concentrations also counting statistics have to be taken into account. The uncertainty in the particle size decreases with particle size and is $\pm 25 \mu \mathrm{m}$ for particles $>125 \mu \mathrm{m}$ in diameter (De Reus et al., 2009).

\subsection{The Spectral Modular Airborne Radiation measurement sysTem (SMART)-Albedometer}

Spectral upwelling radiances and irradiances were measured with the Spectral Modular Airborne Radiation measurement sysTem (SMART)-Albedometer (Wendisch et al., 2001). During the CONCERT campaign, an optical inlet with a viewing angle of $1.5^{\circ}$ designed to measure radiances as well as an irradiance optical inlet (half-dome shape) were each connected to two plain-grated spectrometers, respectively. The optical inlets were placed in the back part of the fuselage of the aircraft. The spectrometers operate in the wavelength ranges 350 to $1050 \mathrm{~nm}$ and 900 to $2200 \mathrm{~nm}$ with spectral resolutions (Full Width at Half Maximum, FWHM) of 2 to $3 \mathrm{~nm}$ and 9 to $16 \mathrm{~nm}$, respectively. The temporal resolution of the measurements is in the order of 0.5 to $3 \mathrm{~s}$, corresponding to a spatial resolution of 100 to $600 \mathrm{~m}$ at an aircraft velocity of $200 \mathrm{~m} / \mathrm{s}$.

\subsection{The Aerosol Mass Spectrometer (AMS)}

The chemical composition and size distribution of submicron aerosol particles were determined by an Aerodyne Compact Time-of-Flight Mass Spectrometer (C-ToF-AMS). The instrument samples aerosol through an aerodynamic lens system which focuses the particle beam onto a vaporizer operated at $600{ }^{\circ} \mathrm{C}$. Before reaching the vaporizer, the particles pass through a time-of-flight region in a vacuum chamber that allows for particle size determination. The vapor is ionized by $70 \mathrm{eV}$ electrons, and the generated ions are analyzed 
in a time-of-flight mass spectrometer. A detailed description of the C-ToF-AMS is given in Drewnick et al. (2005) and Canagaratna et al. (2007). During CONCERT-CHEMISTRY particulate sulfate, ammonium, nitrate, chloride and carbonaceous matter were determined for STP conditions with a time resolution of $10 \mathrm{~s}$. The respective detection limits were 0.02 , $0.13,0.02,0.03$, and $0.11 \mu \mathrm{g} \mathrm{m}^{-3}$ (STP) on campaign average. To compensate for the decreasing mass flow into the instrument with altitude, a pressure controlled inlet (PCI) has been installed in front of the standard AMS inlet system, also guaranteeing isokinetic sampling from the aircraft's aerosol inlet. A thorough description of the inlet system is given in Schmale et al. (2010). This Falcon-specific set-up allowed for sampling of particles in the size range between 84 and $735 \mathrm{~nm}$ vacuum aerodynamic diameter.

\subsection{The Ion Trap Chemical Ionization Mass Spectrometer (ITCIMS)}

An ion trap chemical ionization mass spectrometer (ITCIMS) (Fiedler et al., 2005; Speidel et al., 2007; Fiedler et al., 2009) was for the first time operated with $\mathrm{SF}_{5}^{-}$reagent ions for the detection of $\mathrm{HCl}, \mathrm{HNO}_{3}, \mathrm{SO}_{2}$ and $\mathrm{HONO}$ in the UTLS. A detailed description of the instrument is given in Jurkat et al. (2010). In the flow reactor $\mathrm{SF}_{5}^{-}$reacts with the four trace gases via a fluoride transfer, here exemplarily shown for reactions with $\mathrm{SO}_{2}$ and with $\mathrm{HONO}$ :

$$
\begin{aligned}
& \mathrm{SF}_{5}^{-}\left(\mathrm{H}_{2} \mathrm{O}\right)+\mathrm{SO}_{2} \rightarrow \mathrm{FSO}_{2}^{-}\left(\mathrm{H}_{2} \mathrm{O}\right)+\mathrm{SF}_{4} \\
& \mathrm{SF}_{5}^{-}\left(\mathrm{H}_{2} \mathrm{O}\right)+\mathrm{HONO} \rightarrow \mathrm{FHONO}^{-}\left(\mathrm{H}_{2} \mathrm{O}\right)+\mathrm{SF}_{4}
\end{aligned}
$$

The water clusters are removed through collision with helium injected into the ion trap. Mass spectra from 15 to 170 atomic mass units (amu) with a resolution of $0.3 \mathrm{amu}$ were sampled during a trapping time of $200 \mathrm{~ms}$ and averaged over five spectra resulting in an overall time resolution of $1.6 \mathrm{~s}$. This allowed for the fast and sensitive detection of $\mathrm{SO}_{2}$ and $\mathrm{HONO}$ in young exhaust plumes of commercial airliners and for measurements of $\mathrm{SO}_{2}, \mathrm{HCl}$ and $\mathrm{HNO}_{3}$ in an aged stratospheric plume of volcanic origin. Detection limits for $\mathrm{HONO}$ and $\mathrm{SO}_{2}$ for $1.6 \mathrm{~s}$ time resolution were 72 and $67 \mathrm{pmol} / \mathrm{mol}$ (pptv). Detection limits for $\mathrm{HCl}$ and $\mathrm{HNO}_{3}$ were 22 and $36 \mathrm{pmol} / \mathrm{mol}$ respectively with a running mean over 20 spectra (approx. 32 s). A $\mathrm{HNO}_{3}$ in-flight calibration was performed with a nitric acid permeation source, while $\mathrm{HCl}, \mathrm{SO}_{2}$ and $\mathrm{HONO}$ were calibrated in the laboratory. The HONO calibration of the ion trap mass spectrometer was carried out with a LOPAP instrument (Heland et al., 2001) proving the pseudo first order kinetic reaction (2) given above. The calibration factor accounting for the rate coefficient, the ion molecule reaction time, the dilution and possible wall effects for $\mathrm{SO}_{2}$ and $\mathrm{HONO}$ were 20 and $10 \mathrm{nmol} / \mathrm{mol}$ (ppbv) with an instrumental error of $\pm 25 \%$ and $40 \%$, respectively.

\subsection{The $\mathrm{NO}_{\mathrm{y}}$ instrument}

The $\mathrm{NO}_{\mathrm{y}}$ instrument is described in detail by Ziereis et al. (2004) and Voigt et al. (2005). During the first two weeks of the campaign, it was configured to detect mainly gas phase reactive nitrogen $\mathrm{NO}_{\mathrm{y}, \mathrm{g}}\left(=\mathrm{NO}+\mathrm{NO}_{2}+\mathrm{HONO}+\mathrm{HNO}_{3}+2 \mathrm{~N}_{2} \mathrm{O}_{5}+\mathrm{PAN}+\ldots\right)$ with a backward facing inlet and total $\mathrm{NO}_{\mathrm{y}, \mathrm{t}}\left(=\mathrm{NO}_{\mathrm{y}, \mathrm{g}}+\mathrm{NO}_{\mathrm{y}, \text { part }}\right)$ with a forward facing inlet. Thereafter it monitored mainly gaseous $\mathrm{NO}_{\mathrm{y}, \mathrm{g}}$ and nitric oxide (NO) with two rear facing inlets.

In the rear facing inlets, particles larger than the cut-off size of $d_{50}=0.3 \mu \mathrm{m}$ are inertially stripped from the sampled air, so that predominantly gas phase $\mathrm{NO}_{\mathrm{y}, \mathrm{g}}$ is measured (Voigt et al., 2007). Particles are evaporated in the forward facing inlet releasing gaseous $\mathrm{NO}_{\mathrm{y}, \mathrm{g}} \cdot \mathrm{NO}_{\mathrm{y}, \mathrm{g}}$ is reduced to $\mathrm{NO}$ with $\mathrm{CO}$ in a heated gold converter and the chemiluminescence reaction of $\mathrm{NO}$ with ozone in the infrared is detected with a photo detector. The $\mathrm{NO}_{\mathrm{y}}$ instrument has a detection limit of 1 and $5 \mathrm{pmol} / \mathrm{mol}$ for $\mathrm{NO}$ and $\mathrm{NO}_{\mathrm{y}}$ respectively and an accuracy of $\pm 8 \%$.

\subsection{The Fast In Situ Hygrometer (FISH)}

Water vapor has been measured with the closed path Fast In situ Stratospheric Hygrometer (FISH) (Zöger et al., 1999; Schiller et al., 2008) using the Lyman- $\alpha$ photofragment fluorescence technique. $\mathrm{H}_{2} \mathrm{O}$ mixing ratios between 0.5 and 1000 ppmv have been detected with FISH with a time resolution of $1 \mathrm{~s}$ and an overall accuracy of $6 \%$ or at least $0.3 \mathrm{ppmv}$. FISH is calibrated regularly before, during and after the field campaign using calibration bench including a frost point hygrometer (MBW DP30) as reference. During CONCERT, air is probed by a backward facing inlet tube, i.e. FISH measured gas phase water $\left(\mathrm{H}_{2} \mathrm{O}_{\mathrm{g}}\right)$. Including the uncertainty of $0.5 \mathrm{~K}$ for the temperature measurements, the relative humidity with respect to ice $\left(\mathrm{RH}_{I}\right)$ can be determined with an uncertainty of $\pm 15 \%$.

\subsection{The frost point hygrometer}

In addition, water vapor has been detected with the cryogenic frost point hygrometer CR-2 (Buck Research Instruments, LLC). The instrument measures the temperature of a mirror carrying a thin frost layer that is maintained in equilibrium with the ambient water vapor. The bulk reflectivity of the mirror is measured with an optical detector. It initializes a control circuit to regulate the mirror temperature such that the bulk reflectivity and hence the condensate layer remain constant. The mirror temperature is then equal to the ambient frost point temperature and the water vapor mixing ratio can be calculated using the inverse Clausius-Clapeyron equation. 


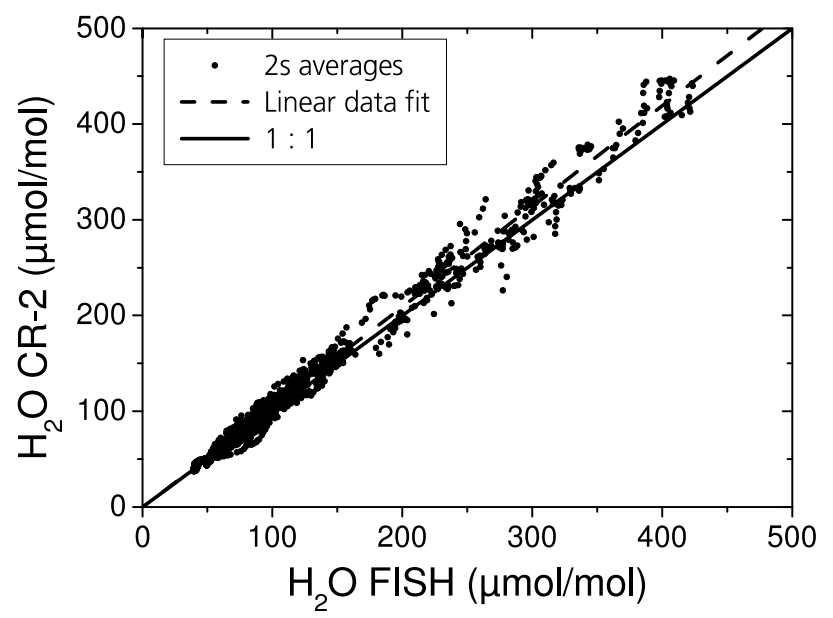

Fig. 1. Correlation of water vapor mixing ratios detected with the frost point hygrometer CR-2 and the Lyman $\alpha$ hygrometer FISH on 20 November 2008 above Germany. The 1:1 line and the linear regression are shown.

The frost point hygrometer has been calibrated to a high accuracy laboratory frost point hygrometer (MBW373 Calibration) during and after the campaign.

The uncertainty of the water vapor mixing ratio is between $\pm 3 \%$ and $\pm 5 \%$ for water vapor mixing ratios between $340 \mu \mathrm{mol} / \mathrm{mol}$ and $40 \mu \mathrm{mol} / \mathrm{mol}$. This uncertainty does not include time-dependent oscillations of the mirror temperature induced by the control circuit after steep gradients in water vapor. Hence the response time of the frost point hygrometer is on the order of several seconds to one minute depending on the water vapor gradient. The CR-2 instrument has been operated for the first time on the Falcon during the CONCERT mission, therefore we show a comparison of the water vapor mixing ratios detected with the CR-2 instrument and Lyman- $\alpha$ hygrometer.

Figure 1 shows the correlation of the water vapor mixing ratios detected with the CR-2 and the FISH instrument during a flight on 20 November 2008 above Germany. The mean water vapor mixing ratio measured by the frost point mirror was $4 \%$ higher than the mixing ratio observed by the Lyman $\alpha$ instrument and lies within the errors of both instruments. The standard deviation of the ratio of the water vapor mixing ratios (CR-2/FISH) is $\pm 7 \%$.

\section{Flight planning and meteorological forecasts}

Research flight planning was based on deterministic meteorological forecasts from the European Centre for MediumRange Weather Forecasts (ECMWF) and on chemical forecasts computed by the MATCH-MPIC model (Lawrence et al., 2003). In addition to the forecast quantities provided by ECMWF, we derived several campaign-specific forecast quantities, for instance, the Schmidt-Appleman cri-

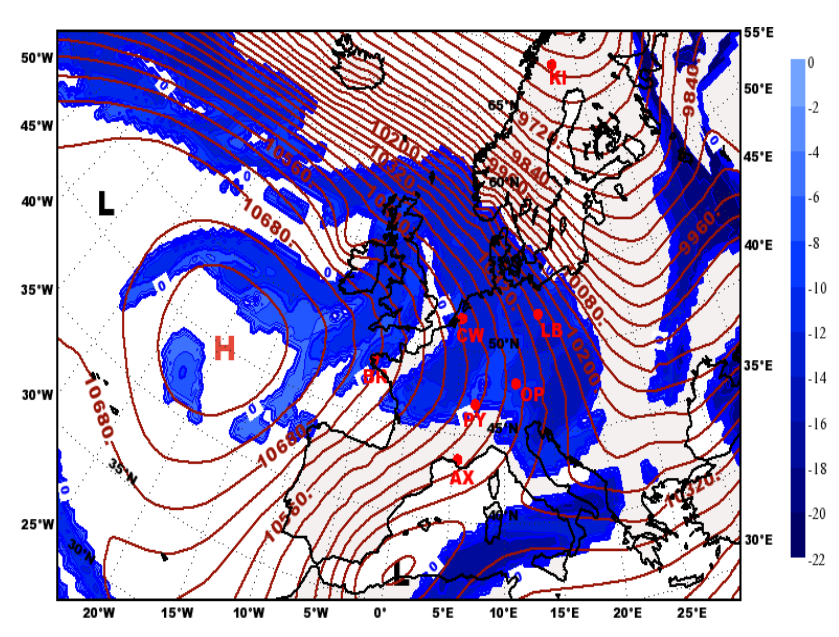

Fig. 2. 36 hour forecast of the Schmidt-Appleman criterion at 250 $\mathrm{hPa}$, valid on 19 November 12 UTC. Shown is the difference between the ambient temperature $(\mathrm{K})$ as forecasted by the ECMWF and the threshold temperature for contrail formation as computed from the Schmidt-Appleman theory. Values are only plotted in regions where the relative humidity is larger than $80 \%$, that is contrails that form in such a region have a high probability to be persistent. Red contours show the geopotential height (m).

terion (Schumann, 1996) to predict regions with a high likelihood of contrail occurrence. Furthermore, the trajectory code LAGRANTO (Wernli et al., 1997) was run on-demand on the ECMWF predicted wind fields in order to estimate how contrails in the flight target regions would be advected.

ECMWF forecasts were visualized with the Metview system (Bonifacio, 1999) and made available to the campaign scientists through a web-based user interface. For fast ondemand LAGRANTO computations, a Python-based user interface was developed. With the information given by the forecast system, we were able to identify target regions with atmospheric conditions well suited to fulfil the mission objectives. Figure 2 shows a plot of the $36 \mathrm{~h}$ forecast of the Schmidt-Appleman criterion combined with regions of high relative humidity, valid on 19 November 2008, 12:00 UTC, at $250 \mathrm{hPa}$. The predictions indicated good conditions for contrail occurrence over Germany and the North Sea. The day was subsequently chosen for targeted contrail observations.

\section{Flight survey}

During the CONCERT campaign, the Falcon performed 12 mission flights on 27, 28, 29 and 31 October and on 2, 7, 17, 19 and 20 November 2008 including 3 return flights on 31 October and on 17 and 19 November. The flight paths from all flights are shown in Fig. 3. Extensive contrail measurements were performed on 2, 17, 19 and 20 November and contrails were also observed on 28 and 29 October, but without FSSP data. The flights on 27 October and on 7 and 


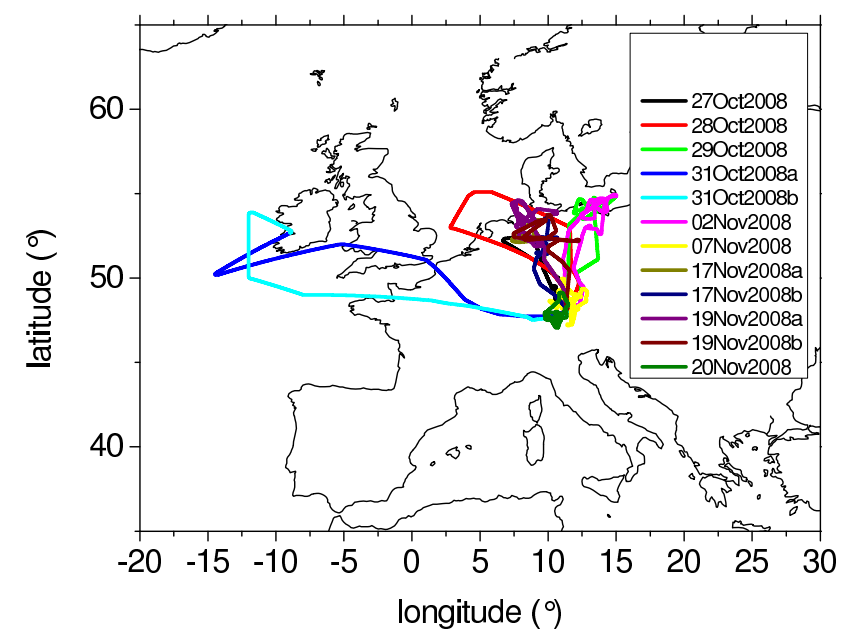

Fig. 3. Trajectories of 12 mission flights performed during the CONCERT (CONtrail and Cirrus ExpeRimenT) campaign in October/November 2008 over Western Europe. The flight dates are given in the legend.

20 November also concentrated on the detection of cirrus clouds. The 31 October return flight from Oberpfaffenhofen to Shannon had the aim to detect regional aircraft emissions from the Northern Atlantic flight corridor. Sampling a stratospheric intrusion was the main goal for the flights on 28 and 31 October.

\section{Detection of young contrails}

Microphysical and optical properties of 22 young contrails were detected by the instruments aboard the Falcon on 8 mission flights. Contrails from 11 different aircraft types were detected, including an A380, several A340s and B767s and B737s, an A319, a CRJ-2 and a Fokker20. The contrails were probed at altitudes between 8.5 to $11.6 \mathrm{~km}$ and at temperatures between 213 and $229 \mathrm{~K}$ (Fig. 4). Contrails were identified from a simultaneous increase in the extinction $>0 \mathrm{~km}^{-1}$ and the NO mixing ratio $>0.2 \mathrm{nmol} / \mathrm{mol}$, latter representing the upper limit for the upper tropospheric NO levels. Further the threshold temperature $T<240 \mathrm{~K}$ was used to exclude lower tropospheric cloud observations. In total $1.7 \mathrm{~h}$ of contrail measurements were achieved. The $\mathrm{RH}_{\mathrm{I}}$ in the contrails ranged between 122 and $55 \%$, with $80 \%$ of the observations concentrating between 105 and $75 \% \mathrm{RH}_{\mathrm{I}}$. Figure 4 (bottom panel) shows that the clear sky $\mathrm{RH}_{\mathrm{I}}$ is also mostly below $100 \%$ with the most frequent observations between $70 \%$ and $100 \%$. Since air from the environment is continuously entrained into the contrails, the slightly sub-saturated conditions in the contrails might portray the clear sky conditions. Including the error in the temperature measurements, the $\mathrm{RH}_{\mathrm{I}}$ has an accuracy of $\pm 15 \%$.

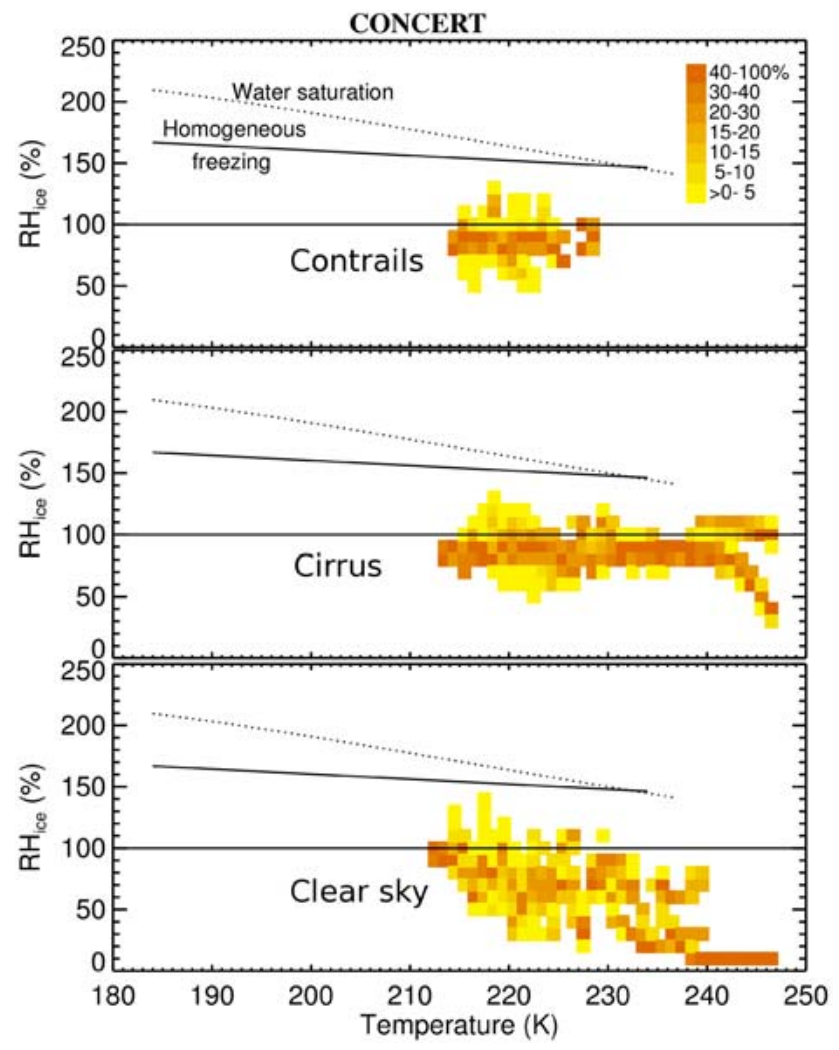

Fig. 4. Frequencies of occurrence of relative humidities over ice versus temperature in contrails (upper panel), cirrus clouds (middle panel) and clear sky (lower panel) observed during the CONCERT campaign. The thin solid line represents the homogeneous freezing threshold, the dotted line refers to water saturation. The data are sorted in $1 \mathrm{~K}$ temperature bins. In each $1 \mathrm{~K}$ bin the sum of all data is $100 \%$.

Contrails were mainly probed in the top region or above visible cirrus clouds, as this sampling strategy was found to be very effective. The contrail sampling strategy was the following: Predictions of the IWC from the ECMWF were used to send the aircraft into the top of a cirrus cloud. The Falcon further ascended above the cloud till contrails were observed by the pilots. The contrail formation altitude was communicated to German Air Traffic Control (DFS), and commercial airliners crossing that region were asked to change their flight altitude to contrail formation altitudes. Thereafter the Falcon was directed behind the airliners and contrails were probed at 10 to 86 nautical miles distance corresponding to contrail ages of 55 to $572 \mathrm{~s}$. During the contrail samplings, the pilots of the commercial aircraft communicated their distance to the Falcon as well as aircraft parameters such as velocity, weight and fuel flow. These parameters were then used to derive emission indices for $\mathrm{NO}_{\mathrm{x}}$ at flight altitude (Schulte et al., 1997; Döpelheuer and Lecht, 1999). 


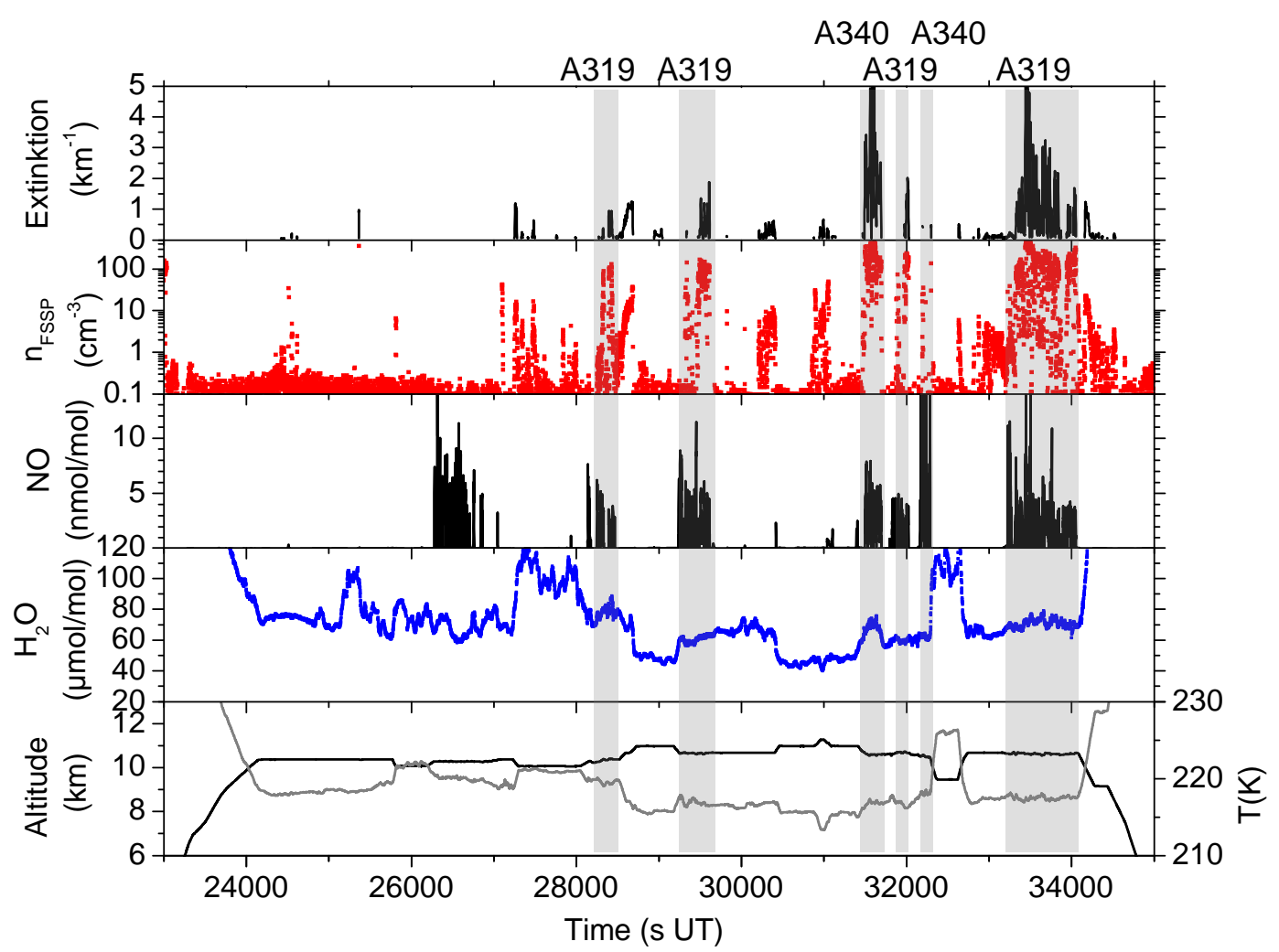

Fig. 5. Contrail flight A on 19 November 2008 above Germany from Oberpfaffenhofen to Hamburg. The flight altitude, temperature, and the $\mathrm{H}_{2} \mathrm{O}$ and NO mixing ratios as well as particle number density detected with the FSSP and the extinction for particles larger than $3 \mu \mathrm{m}$ are shown. Periodic gaps in the NO data are due to calibration events. Sequences of contrail encounters of an A319 and an A340 are marked in gray.

\subsection{Survey of two contrail flights on 19 November 2008}

On 19 November 2008, extensive contrail measurements were performed with the Falcon. We detected 10 contrails above Germany during a return flight from Oberpfaffenhofen to Hamburg and back. During the first flight shown in Fig. 5, we frequently chased an A319, which was a charter aircraft flying specifically for the contrail measurements. The exhaust of the A319 without contrail was detected in the first encounter, thereafter contrails from the A319 were probed four times with the longest contrail encounter of 13 minutes. In addition, the contrail from an A340 was sampled twice. During the return flight, we chased four commercial aircraft and detected the contrails of a B767, a CRJ-2, an A380 and an A320 over Germany as shown in Fig. 6.

Contrail encounters are marked by fast simultaneous increases in the NO mixing ratio, the particle number density detected with the FSSP and the extinction detected with the $\mathrm{PN}$. We attribute contrails to measurements where the extinction is $>0 \mathrm{~km}^{-1}$ and the NO mixing ratio is $>0.2 \mathrm{nmol} / \mathrm{mol}$. In addition, the contrails were filmed by the camera in the cockpit of the Falcon.
Highest NO mixing ratios and extinctions were detected in the contrail of the A380. The contrail was observed for $756 \mathrm{~s}$. NO values up to $58 \mathrm{nmol} / \mathrm{mol}$ were observed and the extinction of particles with $\mathrm{d}>3 \mu \mathrm{m}$ increased to $5.4 \mathrm{~km}^{-1}$ in the A380 contrail. Enhanced particle concentrations $(0.4<$ $d<17.7 \mu \mathrm{m}$ ) up to $537 \mathrm{~cm}^{-3}$ were detected. Average values in the $\mathrm{A} 380$ contrail were lower with a particle concentration of $179 \mathrm{~cm}^{-3}$, NO mixing ratio of $6 \mathrm{nmol} / \mathrm{mol}$ and extinction of $1.6 \mathrm{~km}^{-1}$.

The age of the contrails has been calculated based on the positions of the Falcon and the contrail producing aircraft taking into account the drift of the contrail at the measured wind speed. The ages of the detected contrails were between one and three minutes for the A319, the A340, the B767 and the CRJ-2. The A380 contrail with ages of 1 to $5 \mathrm{~min}$ was detected for 16 minutes. Having left the contrail of the A380, the contrail of an A320 with ages of 8 to 10 min was sampled, representing the oldest contrail observed during the CONCERT campaign. Given contrail ages of less then 10 minutes, all contrails are expected to be line shaped. Hence the contrail measurements were performed in the vortex and the early dispersion regime. 


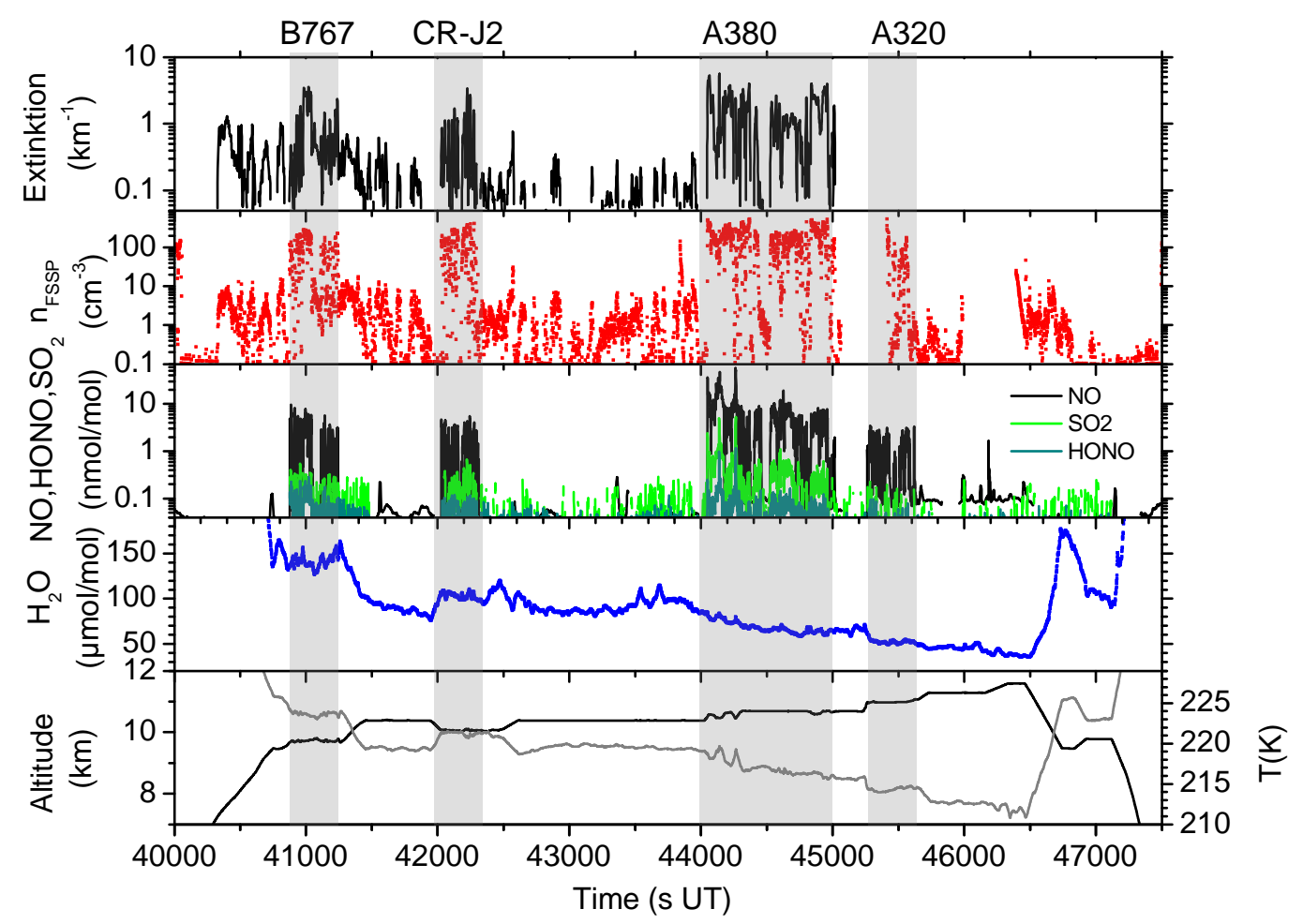

Fig. 6. Contrail flight B on 19 November 2008 above Germany from Hamburg to Oberpfaffenhofen. The flight altitude, temperature, and the $\mathrm{H}_{2} \mathrm{O}, \mathrm{NO}, \mathrm{SO}_{2}$ and $\mathrm{HONO}$ mixing ratios as well as the particle number density detected with the FSSP and the extinction for particles larger than $3 \mu \mathrm{m}$ are shown. Sequences of contrail encounters of a B767, a CRJ-2, an A380 and an A320 are marked in gray. Gaps in the NO, SO 2 and HONO mixing ratios are related to instrument calibrations. The PN stopped working at $45050 \mathrm{~s}$ UT and there is a gap in the FSSP data between $45050 \mathrm{~s}$ and $45410 \mathrm{~s}$ UT.

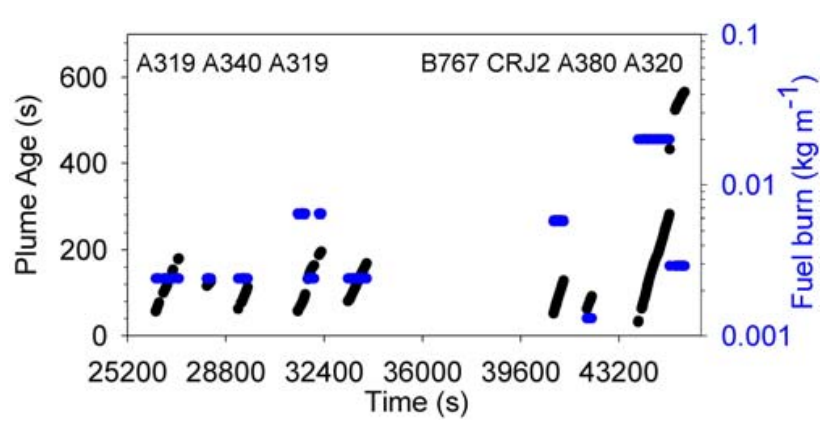

Fig. 7. Plume ages versus Falcon flight time and fuel consumption of the aircraft observed during two flights on 19 November 2008.

\section{Contrail modeling}

A new "Contrail Cirrus Prediction Tool" (CoCiP) has been developed to simulate contrail cirrus resulting from a single flight as well as from a fleet of cruising aircraft, flight by flight, regionally or globally (Schumann, 2010). The method predicts contrail cirrus for given aircraft, traffic and weather prediction data. The method describes the life cycle of individual contrails using a Lagrangian Gaussian plume model, following early concepts (Schumann and Konopka, 1994; Schumann et al., 1995; Konopka, 1995). The turbulent mixing of the plume is mainly controlled by shear but also controlled by turbulent diffusivities; these parameters were selected such that the computed dilution factor (i.e. the mass of the plume per mass of fuel burnt) fits available measurements (Schumann et al., 1998) and LES results (Dürbeck and Gerz, 1996). Contrails are initiated when the SchmidtAppleman criterion is satisfied (Schumann, 1996). The evolution of the individual contrails is computed using wind, temperature, humidity, and ice water content from numerical weather prediction (NWP) output. In our case we use the operational forecast data of the Integrated Forecast System of the ECMWF. This model computes the humidity, allowing for ice supersaturation in air masses without and with cirrus clouds, in fair agreement with observations (Tompkins et al., 2007). The plume trajectory follows horizontal and vertical winds using established methods (Stohl et al., 2001). The ice phase is modelled as a function of bulk contrail ice properties (ice mass and ice particle number). It is assumed that ice particles form on emitted soot particles. The ice water content is computed as a function of mixing and ambient humidity. The model assumes ice saturation inside the contrail. Contrails in 
subsaturated air masses evaporate at time scales depending on the emitted mass of water vapor, the degree of subsaturation and plume dilution. In supersaturated air masses, the contrail ice water content grows by uptake of humidity mixed into the plume from ambient air. The final life time of the contrails in the model is controlled by ice particle loss processes (turbulent mixing, aggregation, sedimentation, radiative heating). These aspects will be described elsewhere and are not important for the present study with young contrails. The climate impact of the contrails (radiative forcing and radiative energy gain per flight distance with contrail) is computed as a function of the contrail properties (width, length, life time, optical depth, temperature, effective radius, optical depth of ambient cirrus above the contrail) using radiative fluxes without contrails from NWP output (Schumann, 2010).

The contrail properties are strongly dependent on the ambient meteorological field (in particular humidity, shear, stratification, and upward motion). In addition the computed contrail properties are aircraft depending (Schumann, 1996). The fuel properties and the propulsion efficiency of the aircraft influence the threshold temperature of contrail formation (Busen and Schumann, 1995). The amount of water vapor emitted in the early contrail contributes to the initial ice water content and hence the life time of the contrail in unsaturated ambient air. The number of soot particles emitted controls the number of ice particles forming in the young contrail (Kärcher and Yu, 2009). Besides fuel consumption, the emission indices (EI) control the computed plume concentrations. The emission index for $\mathrm{NO}_{\mathrm{x}}$ was determined as in Döpelheuer and Lecht (1999) based on aircraft and engine type and the fuel consumption rates reported by the aircraft pilots. The mass, speed and span width of the individual aircraft determine the downward sinking of the wake vortex (Holzäpfel, 2006). The shear driven plume dispersion is strongly enhanced for large wake vortex sinking depths (Schumann et al., 1995). The actual air traffic data (radar observed aircraft type and aircraft positions versus time) were provided for the CONCERT days by the Deutsche Flugsicherung (DFS). The position of the Falcon, measured onboard was found to be in close agreement (50 m laterally, $10 \mathrm{~m}$ vertically) with the DFS observations.

\subsection{Validation of CoCiP model results with CONCERT observations of young contrails}

From the position of the Falcon as a function of time, and the ECMWF forecast wind field (wind speed of order $40 \mathrm{~m} / \mathrm{s}$ ), the model computes the age of the exhaust plume at the time of measurement. The data were accurate enough to decide when the Falcon was in or near the exhaust of aircraft for young plumes (a few minutes) to an age dependent accuracy of order $300 \mathrm{~m}$ horizontally, and $20 \mathrm{~m}$ vertically. Figure 7 shows the plume ages (between 60 and $600 \mathrm{~s}$ ) for the two Falcon flights of 19 November 2008. Also plotted is the fuel

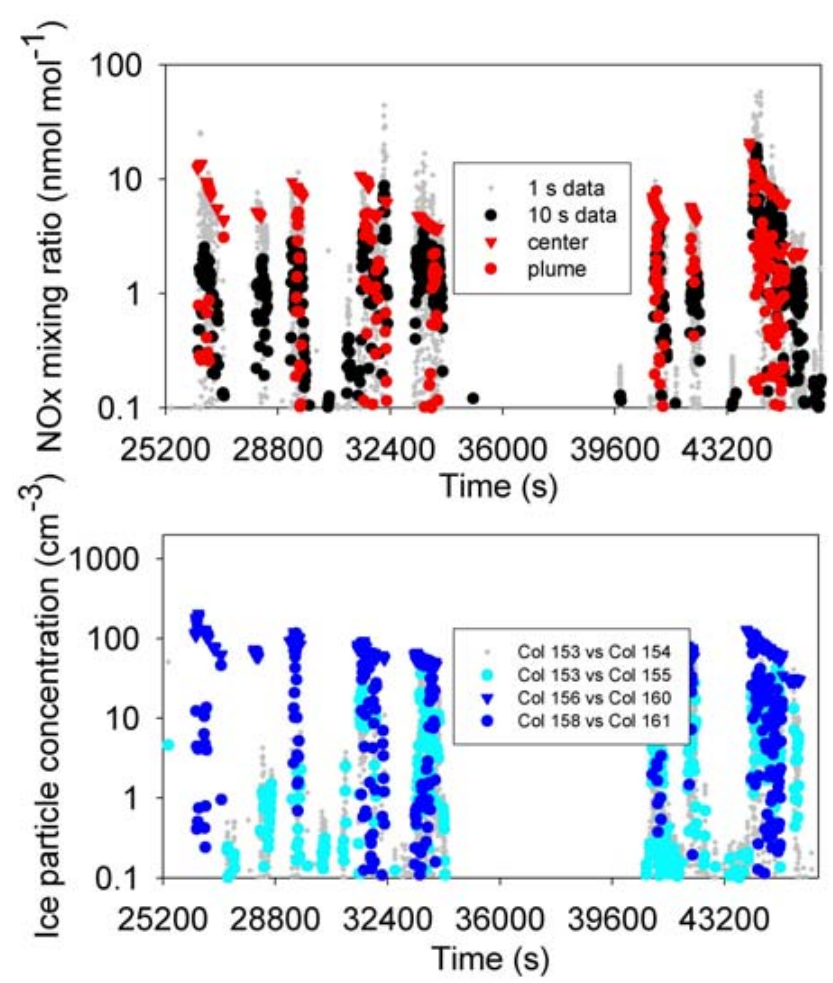

Fig. 8. Comparison of CoCiP model results to contrail observations during two flights on 19 November 2008. Upper panel: NOx mixing ratio versus Falcon flight time. Measured data (grey and black dots) and computed results (red circles: along computed flight path; red triangles: on the plume axis). Lower Panel: Concentration of ice particles larger than $1 \mu \mathrm{m}$ versus Falcon flight time. Measured data (grey and cyan dots) and computed results (blue circles: along computed flight path; blue triangles: on the plume axis).

consumption of the aircraft, which varies by a factor of 20 between the various aircraft. Form a comparison of the computed and measured times of entering the exhaust plume we could see that the model correctly predicts the sinking of the initial wake vortices, up to $270 \mathrm{~m}$ for the heaviest aircraft, to within about $20 \mathrm{~m}$ vertical accuracy. Figure 8 shows the $\mathrm{NO}_{\mathrm{x}}$ mixing ratio versus Falcon flight time. Both 1-s data and 10-s running averages of the measured data are plotted. The latter are commensurable with the model results which do not resolve the turbulent details of the aircraft wake. In the model, the simulated Falcon track does not always lead through the rather narrow (order of $100 \mathrm{~m}$ ) exhaust plume. Hence the model tends to underestimate the maximum measured exhaust concentrations. However, the model can also be applied to compute the plume properties under the assumption that the Falcon at the time of measurement would be flying exactly in the center of the Gaussian plume. In this way, the model provides the maximum exhaust values that are consistent with the Gaussian plume. The $\mathrm{NO}_{\mathrm{x}}$ data reach up to $50 \mathrm{nmol} / \mathrm{mol}$, i.e., far above the background concentrations. Maximum concentrations were measured in the plume 


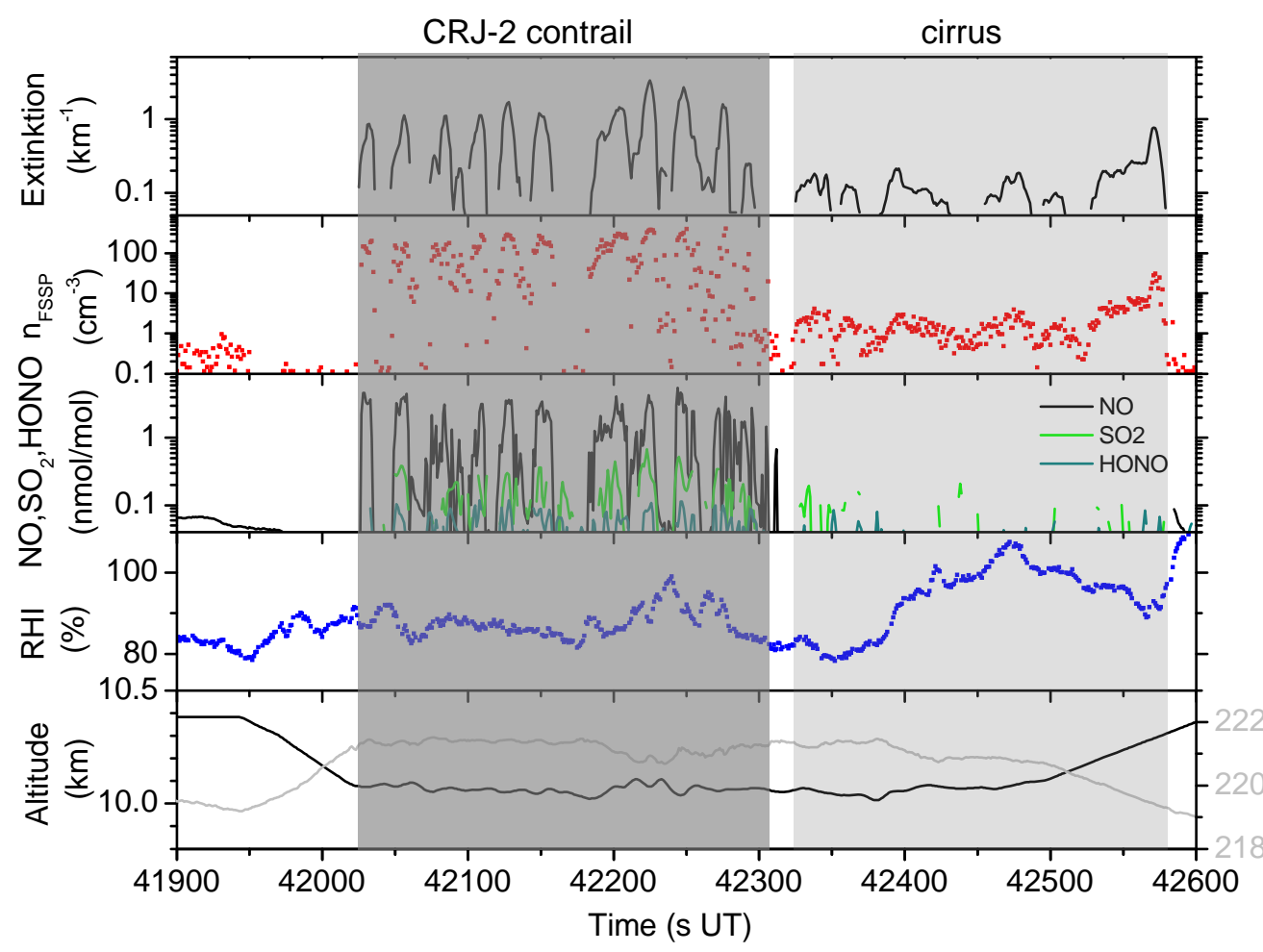

Fig. 9. Observations in the contrail from a CRJ-2 on 19 November 2008 above Germany. The flight altitude, temperature, $\mathrm{RH}_{\mathrm{I}}$, and trace gas mixing ratios of $\mathrm{NO}, \mathrm{SO}_{2}$ and $\mathrm{HONO}$ as well as particle number density detected with the FSSP and extinction for particles larger than $3 \mu \mathrm{m}$ are shown. The contrail (cirrus) sequence is marked in dark (light) gray.

of the biggest aircraft (A380). The maximum concentrations decrease with plume age because of dilution. Figure 8 shows that the model provides $\mathrm{NO}_{\mathrm{x}}$ mixing ratios that are within the scatter of the measured data. The model gives different $\mathrm{NO}_{\mathrm{x}}$ levels in the various plumes which differ because of different plume ages, dilution, fuel consumption and emission indices. For comparable plume ages, the $\mathrm{NO}_{\mathrm{x}}$ concentration is larger for heavier aircraft, mostly with higher emission indices. The results indicate that the model parameters were suitably selected to correctly simulate the dilution in the sheared and turbulent ambient atmosphere. It should be noted that this agreement was obtained after the emission indices had been adjusted for the various aircraft/engine types. The results indicate quite large $\mathrm{NO}_{\mathrm{x}}$ emission indices in some cases up to $27 \mathrm{~g} / \mathrm{kg}$. Figure 8 shows similar results for the ice crystal number concentration in the contrail. The model results and the measurements (for ice particles larger than $1 \mu \mathrm{m}$ ) agree within the scatter of the data. The concentrations reach as high as $100 \mathrm{~cm}^{-3}$ in the contrails. During the first flight the model tends to overestimate the ice particle concentrations and predicts very small ice water content because of the low ambient humidity. The agreement with observations is better during the second flight at higher ambient humidity. The computed ice particle concentration is linearly dependent on the number of soot particles emitted with the exhaust. Hence, this is also a check for the soot number emission indices used $\left(2.4-3.4 \times 10^{15} \mathrm{~kg}^{-1}\right)$. The absolute level of the model results is sensitive to the plume dilution and the loss of ice particles in the adiabatically sinking and thus heating wake core contrail (Sussmann and Gierens, 1999; Unterstrasser and Gierens, 2010; Lewellen and Lewellen, 2001). Again the agreement is such that it supports the basic validity of the model.

CoCiP seems to compute realistic ice particle concentrations. There were no indications of additional ice formation beyond soot induced ice particles. In particular, there are no indications for large contributions from volatile material contributing to ice nucleation for these cases with temperatures of 210 to $222 \mathrm{~K}$. Hence, it seems that the rather complex issue of ice formation in fresh contrails can be explained at accuracy comparable with measurements with a Gaussian plume model and with bulk ice physics and nucleation controlled by the soot particles in the contrail.

The model is computationally efficient enough to be used in forecast mode for operational route optimization with respect to minimum climate impact. Further model tests are underway to explain observed aviation induced cirrus cover diurnal changes over the North Atlantic. Further, the model can be used to evaluate the radiative forcing induced by contrail cirrus formation globally. 


\section{Observation of the contrail from a CRJ-2 aircraft}

Below we discuss in detail the contrail sampling from the CRJ-2 on 19 November 2008. The aircraft was chased between 11:40:23 and 11:45:06 UT above Germany (Fig. 9). The contrail was detected for almost 4.5 minutes at an altitude of 10.02 to $10.11 \mathrm{~km}$ and at temperatures near $221.4 \pm 0.1 \mathrm{~K}$. Elevated extinction for particles larger than $3 \mu \mathrm{m}$ up to $3.3 \mathrm{~km}^{-1}$, particle number concentrations up to $406 \mathrm{~cm}^{-3}$ and NO mixing ratios up to $6 \mathrm{nmol} / \mathrm{mol}$ were measured. Average values in this contrail are $0.8 \mathrm{~km}^{-1}$ in the extinction, $125 \mathrm{~cm}^{-3}$ in the particle concentration and $1.7 \mathrm{nmol} / \mathrm{mol}$ in the $\mathrm{NO}$ mixing ratio. Peak $\mathrm{SO}_{2}$ and $\mathrm{HONO}$ mixing ratios of up to 0.69 and $0.26 \mathrm{nmol} / \mathrm{mol}$ were detected. In the contrail the $\mathrm{RH}_{\mathrm{I}}$ increased to values between 82 and 95\% and was below these values direct before and after the encounter. The contrail was detected at an age of 61 to $122 \mathrm{~s}$ and hence was probed in the vortex regime.

The mean particle surface area and volume distributions detected with the FSSP and the 2D-C in the contrail are shown in Fig. 10. The gap in the particle data between 17.7 and $100 \mu \mathrm{m}$ refers to the particle size range detected by the $\operatorname{FSSP}(0.45<d<17.7 \mu \mathrm{m})$ and the $2 \mathrm{D}-\mathrm{C}(d>100 \mu \mathrm{m})$.

Also shown is the particle size distribution of the surrounding cirrus field. The cirrus cloud has been detected after leaving the contrail from 11:45:06 UT for 5 min as indicated by background $\mathrm{NO}$ and $\mathrm{SO}_{2}$ mixing ratios and elevated extinction and particle number density. The cirrus cloud has been observed at altitudes between 10.1 and $10.4 \mathrm{~km}$ and temperatures of 221 to $219 \mathrm{~K}$. The cirrus particle size distribution (see Fig. 10) suggests that the contrail was embedded in a cirrus cloud and that large cirrus crystals $(d>100 \mu \mathrm{m})$ might have been entrained in the contrail.

It has been questioned whether high ice crystal concentrations often observed with the FSSP are real or were caused by shattering of large ice crystals on protruding probe inlets (McFarquhar et al., 2007; Jensen et al., 2009). Techniques have been proposed (Field et al., 2003, 2006) to correct the particle size distributions based on information of the particles interarrival times (Fast-FSSP or 2D-C) and new particle image probes with high pixel resolution (including CIP and 2D-S) may be used to quantify shattering artefacts. In our cirrus case, the particle concentration may be affected by particle shattering as large ice crystals were detected by the 2D-C and CPI instruments. In contrast, the contrail FSSP-300 measurements are not strongly affected by ice-crystal shattering since the cirrus contribution to the contrail ice crystal surface or volume distribution for particles smaller than $17.7 \mu \mathrm{m}$ is less than $1 \%$ (see Fig. 10), ruling out that the contrail particle size distribution is significantly influenced by shattering. During contrail encounters, the small particle mode with $d<17.7 \mu \mathrm{m}$ is clearly dominated by contrail ice crystals.

The contrail particle size distribution for particles with $0.45<d<17.7 \mu \mathrm{m}$ has a mean total ice crystal surface A of $0.51 \mu \mathrm{m}^{2} \mathrm{~mm}^{-3}$ and a mean contrail ice volume $\mathrm{V}$ of

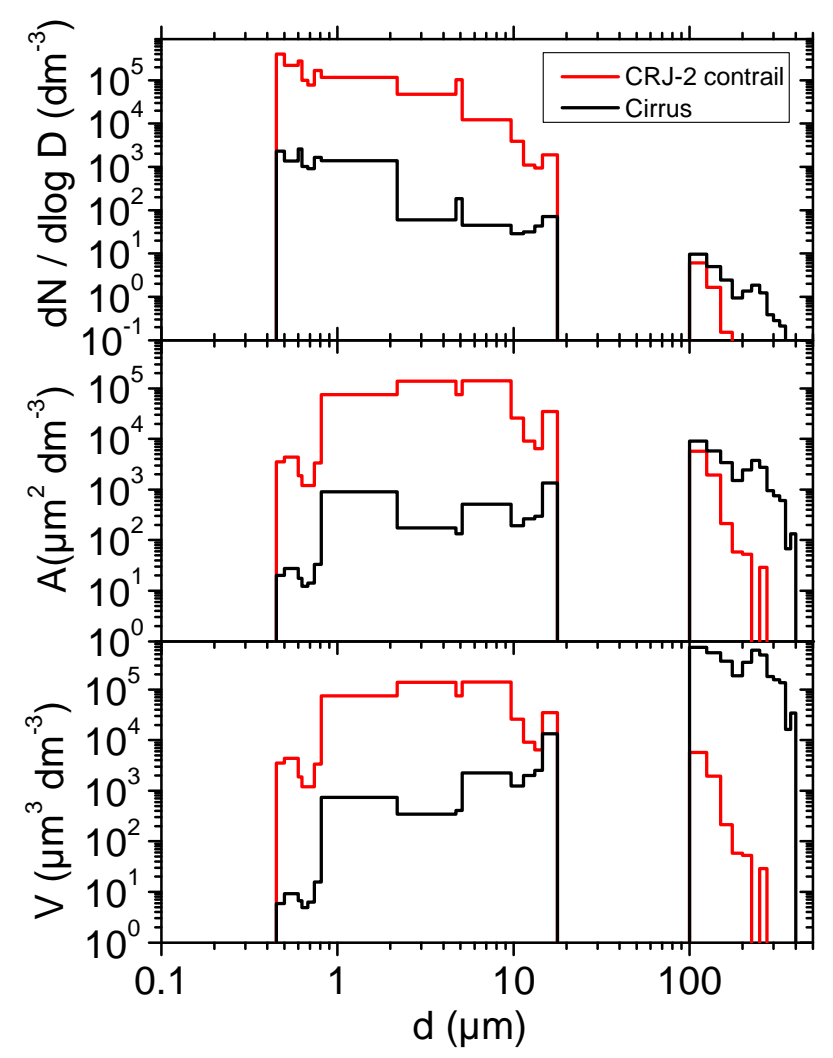

Fig. 10. Particle size, surface and volume distributions of the CRJ-2 contrail (red) embedded in a cirrus cloud (black). The ice surface area (ice volume) is given in $\mu \mathrm{m}^{2} \mathrm{dm}^{-3}$ air $\left(\mu \mathrm{m}^{3} \mathrm{dm}^{-3}\right.$ air) for each size bin. The total ice surface area and total ice volume can be calculated by summing up the individual size bins.

$1.80 \mu \mathrm{m}^{3} \mathrm{~mm}^{-3}$. Using the equation $r_{\mathrm{eff}}=(3 / 4) \mathrm{V} / \mathrm{A}$ yields an effective radius $r_{\text {eff }}$ of $2.6 \mu \mathrm{m}$. Few observation of young contrails with ages of less than 3 minutes exist. The contrail particle size distribution detected during CONCERT broadly agrees with observations in a less then 3 minutes old contrail by Schröder et al. (2000). Similar concentrations of ice crystals $\left(50-300 \mathrm{~cm}^{-3}\right)$ with sizes below $10 \mu \mathrm{m}$ were detected by Baumgardner and Gandrud (1998) in a 30 seconds old contrail at $210 \mathrm{~K}$. Poellot et al. (1999) observed slightly larger particles with mean diameters of $8 \mu \mathrm{m}$ at mean concentrations of $10 \mathrm{~cm}^{-3}$ in contrails older than 3 minutes.

\subsection{Processing of $\mathrm{NO}$ and $\mathrm{SO}_{2}$ in the engine and the plume/contrail from the CRJ-2 aircraft}

Amongst gaseous aircraft emissions, $\mathrm{SO}_{2}$ and $\mathrm{NO}_{\mathrm{x}}$ are the most important precursors for condensable acids that influence particle formation and composition in the upper troposphere. The rate of conversion of fuel sulfur into $\mathrm{H}_{2} \mathrm{SO}_{4}$, $\epsilon_{S}$, has been subject to many investigations (Fahey et al., 1995; Curtius et al., 1998; Miake-Lye et al., 1998) with recent estimates of $\epsilon_{S}$ ranging from 2 to $10 \%$. Simultaneous 
measurements of $\mathrm{HONO}, \mathrm{NO}$ and $\mathrm{SO}_{2}$ in aircraft exhaust plumes under cruise conditions do not exist. HONO/NO ratios have been measured in flight (Arnold et al., 1992) and $\mathrm{HONO} / \mathrm{NO}_{\mathrm{x}}$ ratios on the ground (Wormhoudt et al., 2007; Wood et al., 2008) with an average of $2 \%$ for thrust settings between 30 and $100 \%$.

As an example we discuss here the encounter of the CRJ2 contrail with a CF34-3B engine detected on 19 November 2008 shown in Fig. 6. We observed a good correlation of the NO mixing ratios detected with a chemiluminescence detector and the $\mathrm{HONO}$ and $\mathrm{SO}_{2}$ mixing ratios measured with the ITCIMS instrument. Within the plume HONO mixing ratios range from $0.26 \mathrm{nmol} / \mathrm{mol}$ to values below the detection limit and $\mathrm{SO}_{2}$ shows peak values of $0.69 \mathrm{nmol} / \mathrm{mol}$ with a background of 0.08 to $0.1 \mathrm{nmol} / \mathrm{mol}$.

The HONO/NO ratio was calculated by integrating over all measurements in the contrail to account for the different time resolution of the two instruments. For this aircraft and plume ages of 62 to $122 \mathrm{~s}, \mathrm{HONO} / \mathrm{NO}\left(\mathrm{HONO} / \mathrm{NO}_{\mathrm{y}}\right)$ ratios were 0.037 (0.024) with an instrumental error of $\pm 42 \%$. The high $\mathrm{HONO} / \mathrm{NO}$ value suggests that $\mathrm{NO}$ conversion to $\mathrm{NO}_{2}$ has occurred within in the first minute after emission. Higher $\mathrm{HONO} / \mathrm{NO}$ values are therefore expected in aging plumes compared to measurements at the engine exit (Wood et al., 2008).

In order to derive the conversion efficiency of fuel sulfur $\epsilon_{S}$ in the engine we compare the two formation pathways of $\mathrm{HONO}$ and $\mathrm{HSO}_{3}$ (a precursor of $\mathrm{H}_{2} \mathrm{SO}_{4}$ ) in the turbine segment of the engine. A major part of the $\mathrm{OH}$-induced conversion of the precursor gases $\mathrm{SO}_{2}$ and $\mathrm{NO}$ takes place in the combustion chamber and the turbine segment of the engine (Kärcher et al., 1996; Somnitz et al., 2005). Here $\mathrm{SO}_{2}$ reacts with $\mathrm{OH}$ via the Stockwell-Calvert-Mechanism to form $\mathrm{H}_{2} \mathrm{SO}_{4}$ and $\mathrm{NO}$ reacts directly with hydroxyl radicals to form HONO. Under the assumption that the ratio of the effective rate coefficients for the two reactions is near unity the sulfur conversion efficiency can be inferred.

In the case of the CRJ-2 the fuel sulfur conversion efficiency yields a value of $2.9 \%$. This fraction can be regarded as a lower limit because our method accounts specifically for the $\mathrm{OH}$-induced conversion of $\mathrm{SO}_{2}$. This lower limit is in good agreement with recent model simulations of the sulfur conversion efficiency (Starik et al., 2002), and compares well with former direct in-situ measurements of total sulfuric acid (Curtius et al., 2002) in aircraft exhaust plumes. The uncertainty of the method arises from the uncertainty of the effective rate coefficients for the reaction $\mathrm{SO}_{2}+\mathrm{OH}$ and $\mathrm{NO}$ $+\mathrm{OH}$. The advantage of this method to derive the sulfur conversion efficiency is that it is independent of dilution and the initial $\mathrm{OH}$ concentration and it benefits from reliable trace gas measurements.
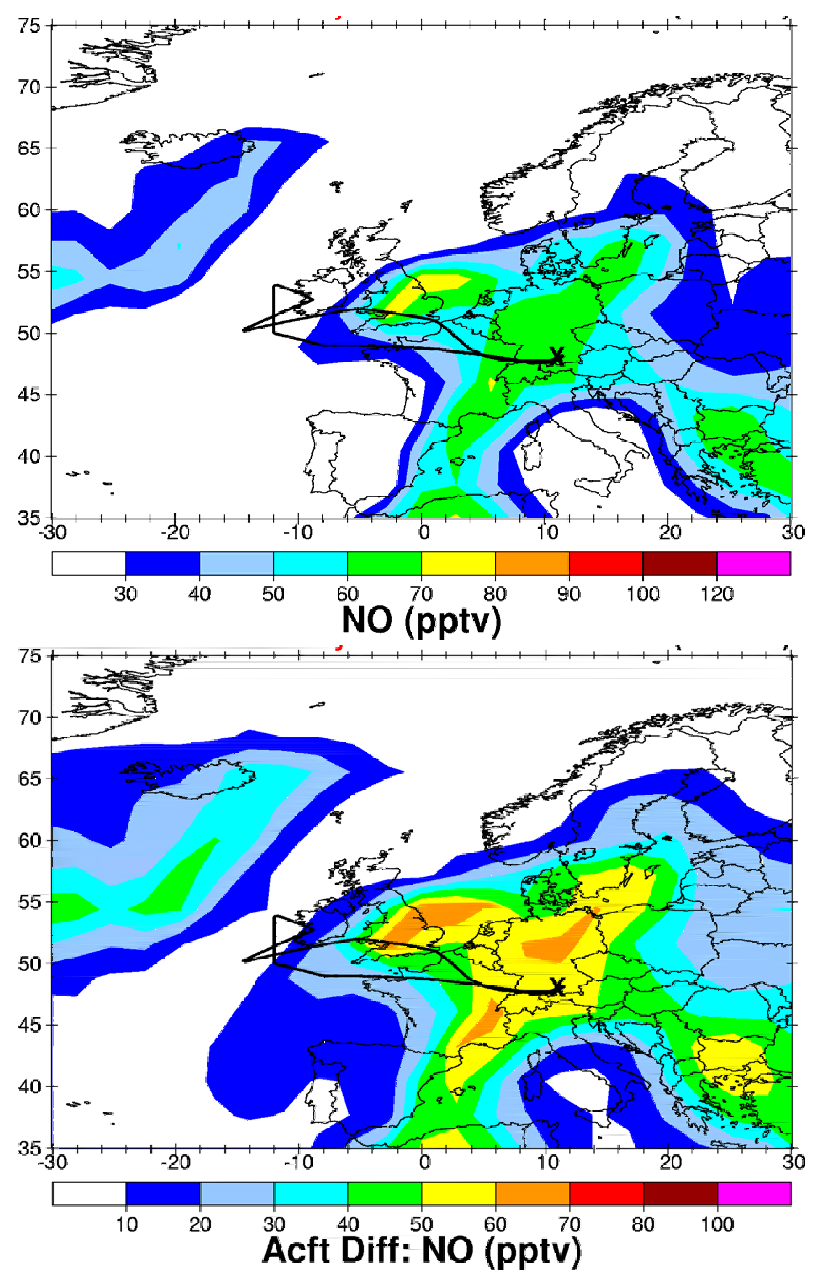

Fig. 11. Simulations with the MATCH-MPIC model of background NO (upper panel) and aircraft NO emissions (lower panel) on 31 October 2008, $12 \mathrm{UT}$, at $250 \mathrm{hPa}$ above Europe. Also shown is the flight trajectory of the Falcon (a return flight from Oberpfaffenhofen to Shannon, black line).

\section{Aircraft NO corridor effects in the lowermost stratosphere}

Besides small scale plume processing also the detection of regional scale aircraft emissions were within the scope of the CONCERT campaign.

Therefore, the MATCH-MPIC model (Lawrence et al., 2003) was used for the prediction of regional aircraft NO emissions. The MATCH-MPIC model is a global, three dimensional chemical transport model driven by meteorological analyses and forecasts from NCEP (National Centers for Environmental Prediction). During the CONCERT campaign, MATCH-MPIC was run semi-operationally in two configurations, one with, and the other without aircraft NO emissions. Aircraft emissions used for these simulations are described by Schmitt and Brunner (1997). Examination of 


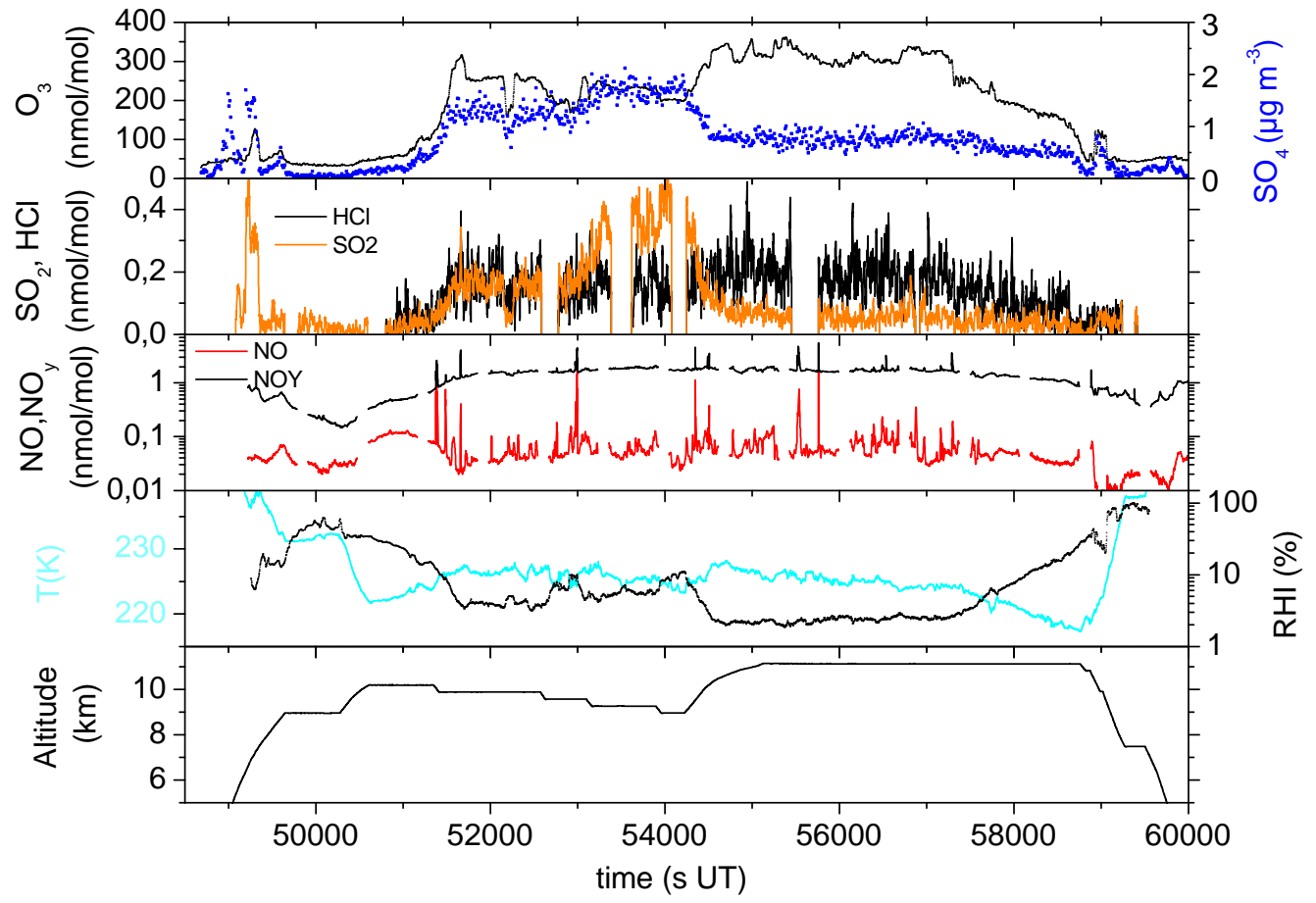

Fig. 12. Altitude, temperature, $\mathrm{RH}_{\mathrm{I}}, \mathrm{NO}, \mathrm{NO}_{\mathrm{y}}, \mathrm{O}_{3}, \mathrm{SO}_{2}, \mathrm{HCl}$, and sulfate concentrations detected on 31 October 2008 on flight $\mathrm{B}$ from Shannon to Oberpfaffenhofen. Large scale aircraft emissions in the lowest stratosphere and the aged eruption plume from volcano Mt. Kasatochi have been observed.

the differences between the output from these two model configurations allowed the prediction of large-scale regions influenced by aircraft emissions. Fig. 11 shows examples of the background and the aircraft NO predictions for $31 \mathrm{Oc}-$ tober 2008, $12 \mathrm{UTC}$, at $250 \mathrm{hPa}$ including the flight path of the Falcon. The simulations show an extended feature above Great Britain with elevated NO concentrations of up to $80 \mathrm{pmol} / \mathrm{mol}$. In this region aircraft emissions additionally contribute up to $70 \mathrm{pmol} / \mathrm{mol}$ to atmospheric background concentrations, suggesting that more than $40 \%$ of the total NO might originate from aircraft emissions. This day was subsequently chosen for a flight to detect aircraft NO corridor effects.

The region with enhanced NO was crossed twice by the Falcon on 31 October during a return flight from Oberpfaffenhofen to Shannon and back in the lowest stratosphere at altitudes between 10.5 and $11.6 \mathrm{~km}$ (Fig. 12). The detection of spikes in the $\mathrm{NO}$ and $\mathrm{NO}_{\mathrm{y}}$ data within that region shows the presence of aircraft exhaust plumes with ages of minutes up to few hours (Schumann et al., 1998). The detection of aircraft plumes and their superposition is a first indication for the observation of aircraft corridor $\mathrm{NO}_{\mathrm{x}}$ effects. In addition to the individual aircraft plumes, large scale elevated NO mixing ratios of 50 to $100 \mathrm{pmol} / \mathrm{mol}$ were detected in the lower stratosphere within the region influenced by the aircraft emissions compared to unperturbed stratospheric NO levels $<50 \mathrm{pmol} / \mathrm{mol}$. The measurements qualitatively agree with simulations with the MATCH-MPIC model of background and aircraft NO mixing ratios above Europe (Fig. 11). Hence we suggest that elevated NO levels in that region might be attributed to the superposition and dispersion of aged aircraft plumes and to regional aircraft NO effects. Our first rough analysis invites for a detailed study of the impact of aircraft NO in atmospheric composition. While several studies of the aircraft $\mathrm{NO}_{\mathrm{x}}$ impact in the upper troposphere exist (Schlager et al., 1997, 1999; Ziereis et al., 1999; Schumann et al., 2000), our measurements present a rare observation (Kondo et al., 1999; Koike et al., 2000) of a substantial large scale aircraft NO effect in the lowermost mid latitude stratosphere.

\section{Detection of aged stratospheric aerosol layers from volcano Mt. Kasatochi}

A natural source of particles and trace gases in the UTLS region are major volcanic eruptions. Volcanic eruptions inject sulfur into the stratosphere, preferably as gaseous $\mathrm{SO}_{2}$, which undergoes stratospheric conversion to sulfuric acid and ultimately to sulfate aerosols. Increased aerosol surface areas after major volcanic eruptions increase the planetary albedo, resulting in transient global surface cooling lasting for about 1 to 2 years. In addition, volcanic eruptions may also inject chlorine species into the stratosphere, as gaseous 
$\mathrm{HCl}$ or as $\mathrm{NaCl}$ particles. Depending on the $\mathrm{RH}_{\mathrm{I}}$ within the eruption plume, a significant fraction of the emitted gaseous $\mathrm{HCl}$ can reach the stratosphere (Textor et al., 2003). Halogen activation on volcanic aerosol can contribute to ozone loss in the lowest stratosphere (Borrmann et al., 1997; Solomon et al., 1998) .

An aged volcanic eruption plume was observed during 3 CONCERT flights in the lowest stratosphere. The plume originated from the 7/8 August 2008 eruption of the Aleutian volcano Kasatochi $\left(52^{\circ} \mathrm{N}\right)$, which injected about $1.5 \mathrm{Mt}$ of $\mathrm{SO}_{2}$ into the lower stratosphere, representing a rare case of a major volcanic eruption in northern high latitudes. We measured the eruption plume three month later on 28 October and on two flights on 31 October (Fig. 12) in a stratospheric tongue extending over Western Europe. As the Falcon cruised at 8.5 to $11 \mathrm{~km}$ altitude, two stratified plumes were sighted as dark bands against the horizon. The $\mathrm{SO}_{2}$ and the sulfate aerosol measurements revealed the presence of two major sulfate aerosol layers extending up to $5 \mathrm{~km}$ above the local tropopause. The observed sulfate concentration of $2.0 \mathrm{\mu gm}^{-3}$ was significantly enhanced compared to background concentrations of $0.5 \mu \mathrm{gm}^{-3}$ (Schmale et al., 2010). The increase of sulfate is most likely due to stratospheric $\mathrm{OH}$-induced conversion of injected volcanic $\mathrm{SO}_{2}$ leading to gaseous sulfuric acid, followed by condensation. The maximum $\mathrm{SO}_{2}$ mixing ratio of $510 \mathrm{pmol} / \mathrm{mol}$ in the plume very substantially exceeded the atmospheric background $\mathrm{SO}_{2}$ of about $40 \mathrm{pmol} / \mathrm{mol}$ (Jurkat et al., 2010). The ratio of particulate sulfate to total sulfur inside the plume of $0.8 \pm 0.1$ reflects slow $\mathrm{OH}$-induced $\mathrm{SO}_{2}$ conversion to sulfuric acid with an upper limit of the e-folding $\mathrm{SO}_{2}$ lifetime of 60 days (Jurkat et al., 2010).

Additional trace gas measurements of $\mathrm{HCl}, \mathrm{HNO}_{3}$ and $\mathrm{O}_{3}$ allow to investigate heterogeneous reactions taking place on the sulfate particles. The ratio $\mathrm{HCl} / \mathrm{O}_{3}$ tends to be increased by $19 \%$ in the $\mathrm{SO}_{2}$-rich plumes compared to outside plume conditions suggesting direct injection of volcanic $\mathrm{HCl}$ into the stratosphere and very slow processing of $\mathrm{HCl}$ on the aerosol in the polar summer stratosphere. $\mathrm{HNO}_{3} / \mathrm{O}_{3}$ was enhanced by $50 \%$ in the plumes suggesting increased $\mathrm{N}_{2} \mathrm{O}_{5}$ hydrolysis on enhanced sulfate aerosols (Jurkat et al., 2010).

$21 \%$ of the volcanic aerosol consisted of carbonaceous material, which is factor of 1.4 more than observed in UTLS background aerosol (Schmale et al., 2010). The increase of organic species may be due to direct injection of organic aerosol into the stratosphere. Alternatively, organic aerosol may form in the lower stratosphere from injected organic precursor gases, which became entrained into the tropospheric segment of the eruption column. The increased organic aerosol fraction might influence uptake coefficients and heterogeneous processing on volcanic sulfate aerosol.

\section{Conclusions}

Chemical, microphysical and radiative properties of contrails, cirrus clouds and an aged volcanic aerosol layer were detected during the CONCERT campaign in October/November 2008 over Western Europe and were compared to model simulations. The observations of microphysical and chemical contrail properties provide a solid base for future studies.

Of particular interest is the first detection of the contrail from an A380-800 aircraft and the temporal evolution of particle size distribution and particle shape in the contrail. Further the mixing of contrail ice crystals with ambient cirrus cloud particles and the evaporation of contrail ice crystals under ice sub-saturated conditions can be addressed with model simulations. Particle properties such as the ratio between the volume mean and the effective radius of contrail ice crystals can be discussed. The chemical processing of trace gases in contrails and the large scale perturbation of the UTLS composition by aircraft emissions can be studied in detail. The contrail observations during the CONCERT campaign further allow to calculate the radiative forcing from contrails from a typical present-day aircraft fleet.

Acknowledgements. The CONCERT campaign was organized by the HGF-junior research group AEROTROP (Impact of Aircraft Emissions on the heteROgeneous chemistry of the TROPopause region). Part of this work was funded within the DLR-project CATS (Climate-compatible Air Transport System) and by the DFG SPP HALO 1294. We thank the DLR flight department for their excellent support during the campaign. A. Giez is greatfully acknowledged for his help with the calibration of the dewpoint hygrometer. ECMWF forecasts were provided in the context of the ECMWF Special Project: Support Tool for HALO Missions.

Edited by: O. Möhler

\section{References}

Arnold, F., Scheid, J., Stilp, T., Schlager, H., and Reinhardt, M. E.: Measurements of jet aircraft emissions at cruise altitude $\mathrm{I}$ : the odd- nitrogen gases $\mathrm{NO}, \mathrm{NO}_{2}, \mathrm{HNO}_{2}$ and $\mathrm{HNO}_{3}$, Geophys. Res. Lett., 19, 2421-2424, 1992.

Baumgardner, D., Dye, J. E.,Gandrud, B. W., and Knollenberg, R. G.: Interpretation of measurements made by the Forward Scattering Spectrometer Probe (FSSP-300) during the airborne arctic stratosphere expedition, J. Geophys. Res., 97, 8035-8046, 1992.

Baumgardner, D. and Gandrud, B. E.: A comparison of the microphysical and optical properties of particles in an aircraft contrail and mountain wave cloud, Geophys. Res. Lett., 25(8), 11291132, doi:10.1029/98GL00035, 1998.

Bonifacio, R.: METVIEW - Meteorological data visualisation and processing software at ECMWF, ECMWF Newsletter 86, Winter 1999/2000, 6-18,1999.

Borrmann, S., Solomon, S., Dye, J., Baumgardner, D., Kelly, K., and Chan, K.: Heterogeneous reactions on stratospheric background aerosols, volcanic sulfuric acid droplets, and type I po- 
lar stratospheric clouds: Effects of temperature fluctuations and differences in particle phase, J. Geophys. Res., 102(D3), 36393648, 1997.

Borrmann, S., Luo, B., and Mishchenko, M.: Application of the T-matrix method to the measurement of aspherical (ellipsoidal) particles with forward scattering optical particle counters, J. Aerosol Sci., 31, 789-799, 2000.

Busen, R., and Schumann, U.: Visible contrail formation from fuels with different sulfur contents, Geophys. Res. Lett., 22, 13571360, doi:10.1029/95GL01312, 1995.

Curtius, J., Sierau, B., Arnold, F., Baumann, R., Busen, R., Schulte, P., and Schumann, U.: First Direct Sulfuric Acid Detection in the Exhaust Plume of a Jet Aircraft in Flight, Geophys. Res. Lett., 25(6), 923-926, doi:10.1029/98GL00512, 1998.

Curtius, J., Arnold, F., and Schulte, P.: Sulfuric acid measurements in the exhaust plume of a jet aircraft in flight: Implications for the sulfuric acid formation efficiency, Geophys. Res. Lett., 29(7), 1113-1116, doi:10.1029/2001GL013813, 2002.

Canagaratna, M. R., Jayne, J. T., Jimenez, J. L., Allan, J. D., Alfarra, M. R., Zhang, Q., Onasch, T. B., Drewnick, F., Coe, H., Middlebrook, A., et al., Chemical and microphysical characterization of ambient aerosols with the aerodyne aerosol mass spectrometer, Mass Spectrom. Rev., 26(2), 185-222, doi:10.1002/mas.20115, 2007.

de Reus, M., Borrmann, S., Heymsfield, A. J., Weigel, R., Schiller, C., Mitev, V., Frey, W., Kunkel, D., Kürten, A., Curtius, J., Sitnikov, N. M., Ulanovsky, A., and Ravegnani, F.: Evidence for ice particles in the tropical stratosphere from in-situ measurements, Atmos. Chem. Phys., 9, 6775-6792, doi:10.5194/acp-96775-2009, 2009.

Drewnick, F., Hings, S. S., DeCarlo, P., Jayne, J. T., Gonin, M., Fuhrer, K., Weimer, S., Jimenez, J. L., Demerjian, K. L., Borrmann, S., et al., A new time-of-flight aerosol mass spectrometer (TOF-AMS) - Instrument description and first field deployment, Aerosol Sci. Technol., 39(7), 637658,doi:10.1080/02786820500182040, 2005.

Döpelheuer, A. und Lecht, M.: Influence of engine performance on emission characteristics, Gas Turbine Engine Combustion, Emissions and Alternative Fuels, Canada Communication Group. Inc., 1999.

Dürbeck, T. and Gerz, T.: Dispersion of aircraft exhausts in the free atmosphere, J. Geophys. Res., 101, 26007-26015, 1996.

Fahey, D. W., Eubank, C. S., Hubler, G., and Fehsenfeld, F. C.: Evaluation of a catalytic reduction technique for the measurement of total reactive odd-nitrogen $\mathrm{NO}_{\mathrm{y}}$ in the atmosphere, J. Atmos. Chem., 3, 435-468, 1985.

Fahey, D. W., Keim, E. R., Boering, K. A., Brock, C. A., Wilson, J. C., Jonsson, H. H., Anthony, S., Hanisco, T. F., Wennberg, P. O., Miake-Lye, R. C., Salawitch, R. J., Louisnard, N., Woodbridge, E. L., Gao, R. S., Donnelly, S. G., Wamsley, R. C., Negro, L. A. D., Solomon, S., Daube, B. C., Wofsy, S. C., Webster, C. R., May, R. D., Kelly, K. K., Loewenstein, M., and Podolske, J. R.: Emission Measurements of the Concorde Supersonic Aircraft in the Lower Stratosphere, Science, 270, 70-74, doi:10.1126/science.270.5233.70, 1995.

Febvre, G., Gayet, J.-F., Minikin, A., Schlager, H., Shcherbakov, V., Jourdan, O., Busen, R., Fiebig, M., Kärcher, B., and Schumann, U.: On optical and microphysical characteristics of contrails and cirrus, J. Geophys. Res., 114, D02204, doi:10.1029/
2008JD010184, 2009.

Fiedler, V., Dal Maso, M., Boy, M., Aufmhoff, H., Hoffmann, J., Schuck, T., Birmili, W., Hanke, M., Uecker, J., Arnold, F., and Kulmala, M.: The contribution of sulphuric acid to atmospheric particle formation and growth: a comparison between boundary layers in Northern and Central Europe, Atmos. Chem. Phys., 5, 1773-1785, doi:10.5194/acp-5-1773-2005, 2005.

Fiedler, V., Nau, R., Ludmann, S., Arnold, F., Schlager, H., and Stohl, A.: East Asian $\mathrm{SO}_{2}$ pollution plume over Europe - Part 1: Airborne trace gas measurements and source identification by particle dispersion model simulations, Atmos. Chem. Phys., 9, 4717-4728, doi:10.5194/acp-9-4717-2009, 2009.

Field, P. R., Wood, R., Brown, P. R. A., Kaye, P. H., Hirst, E., Greenaway, R., and Smith, J.: Ice particle interarrival times measured with a Fast FSSP, J. Atmos. Oceanic Technol., 20, 249261, 2003.

Field, P. R., Heymsfield, A. J., and Bansemer A.: Shattering and interarrival times measured by optical array probes in ice clouds, J. Atmos. Ocean. Technol., 23, 1357-1371, 2006.

Freudenthaler, V., Homburg, F., and Jäger, H.: Contrail observations by ground-based scanning Lidar: Cross-sectional growth, Geophys. Res. Lett., 22, 3501-3504, 1995.

Gao, R. S., Popp, P. J., Fahey, D. W., Marcy, T. P., Herman, R. L., Weinstock, E. M., Baumgardner, D., Garrett, T. J., Rosenlof, K. H., Thompson, T. L., Bui, T. P., Ridley, B. A., Wofsy, S. C., Toon, O. B., Tolbert, M. A., Kärcher, B., Peter, T., Hudson, P. K., Weinheimer, A. J., and Heymsfield, A. J.: Evidence that nitric acid increases relative humidity in low-temperature cirrus clouds, Science, 303, 516-520, 2004.

Gayet, J.-F., Treffeisen, R., Helbig, A., Bareiss, J., Matsuki, A., Herber, A., and Schwarzenboeck, A.: On the onset of the ice phase in boundary layer Arctic clouds, Journal of Geophysical Research., 114, D19201, doi:10.1029/2008JD011348, 2009.

Heland, J., Kleffmann, J., Kurtenbach, R., and Wiesen, P.: A New Instrument To Measure Gaseous Nitrous Acid (HONO) in the Atmosphere, Environm. Sci. Tech., 35, 3207-3212, doi:10.1021/es000303t, 2001.

Heymsfield, A. J.: Ice crystal terminal velocities, J. Atmos. Sci., 29, 1348-1366, 1972.

Heymsfield, A. J. and Parrish, J. L.: A computational technique for increasing the effective sampling volume of the PMS twodimensional particle size spectrometer, J. Appl. Meteor., 17, 1566-1572, 1978.

Heymsfield, A. J., Lawson, R. P., and Sachse, G. W.: Growth of ice crystals in a precipitating contrail, Geophys. Res. Lett., 25, 13351338, 1998.

Heymsfield, A. J.: On measurements of small ice particles in clouds, Geophys. Res. Lett., 34, L23812, doi:10.1029/ 2007GL030951, 2007.

Holzäpfel, F.: Probabilistic Two-Phase Aircraft Wake- Vortex Model: Further Development and Assessment, J. Aircraft, 43, 700-708, 2006.

E. J. Jensen, Toon, O. B., Pueschel, R. F., Goodman, J., Sachse, G. W., Anderson, B. E., Chan, K. R., Baumgardner, D., and MiakeLye, R. C.: Ice crystal nucleation and growth in contrails forming at low ambient temperatures, Geophys. Res. Lett., 25(9), 13711374, 1998.

Jensen, E., Lawson, P. , Baker, B., Pilson, B., Mo, Q., Heymsfield, A. J., Bansemer, A., Bui, T. P., McGill, M., Hlavka, D., 
Heymsfield, G., Platnick, S., Arnold, G. T. and Tanelli, S.: On the importance of small ice crystals in tropical anvil cirrus, Atmos. Chem. Phys., 9, 5519-5537, doi:10.5194/acp-9-5519-2009, 2009.

Jurkat, T., Voigt, C., Arnold, F., Schlager, H., Aufmhoff, H., Schmale, J., Scheider, J., Lichtenstern, M., and Dörnbrack, A.: Airborne ITCIMS-measurements of $\mathrm{SO}_{2}, \mathrm{HCl}$, and $\mathrm{HNO}_{3}$ in the aged stratospheric plume of volcano Mt. Kasatochi, J. Geophys. Res., doi:10.1029/2010JD013890, in press, 2010.

Kärcher, B.: Aircraft-generated aerosols and visible contrails, Geophys. Res. Lett., 23, 1933-1936, 1996.

Kärcher, B., Hirschberg, M. M., and Fabian, P.: Small-scale chemical evolution of aircraft exhaust species at cruising altitudes, J. Geophys. Res., 101, 15169-15190, 1996.

Kärcher, B., Turco, R., Yu, F., Danilin, M., Weisenstein, D., MiakeLye, R., and Busen, R.: A unified model for ultrafine aircraft particle emissions, J. Geophys. Res., 105, 29379-29386, 2000.

Kärcher, B. and Voigt, C.: Formation of nitric acid/water ice particles in cirrus clouds, Geophys. Res. Lett., 33, L08806, doi: 10.1029/2006GL025927, 2006.

Kärcher, B., Abbatt, J. P. D., Cox, R. A., Popp, P. J., and Voigt, C.: Trapping of trace gases by growing ice surfaces including surface-saturated adsorption, J. Geophys. Res., 114, doi:10.1029/2009JD011857, 2009.

Kärcher, B., and Yu, F.: Role of aircraft soot emissions in contrail formation, Geophys. Res. Lett., 36, L01804, doi:10.1029/2008GL036649, 2009.

Koike, M., Kondo, Y., Ikeda, H., Gregory, G. L., Anderson, B. E., Sachse, G. W., Blake, D. R., Lib, S. C., Singh, H. B., Thompson, A. M., Kita, K., Zhao, Y., Sugita, T., Shetter, R. E., and Toriyama, N.: Impact of aircraft emissions on reactive nitrogen over the North Atlantic Flight Corridor region, J. Geophys. Res., 105(D3), 3665-3677, 2000.

Kondo, Y., Koike, M. Ikeda, H., Anderson, B. E., Brunke, K. E., Zhao, Y., Kita, K., Sugita, T., Singh, H. B., Liu, S. C., Thompson, A., Gregory, G. L., Shetter, R., Sachse, G., Vay, S. A., Browell, E. V., and Mahoney, M. J.:Impact of aircraft emissions on NOx in the lowermost stratosphere at northern midlatitudes, Geophys. Res. Lett., 26, 3065-3068, 1999.

Kondo, Y., Toon, O. B., Irie, H., Gamblin, B., Koike, M., Takegawa, N., Tolbert, M. A., Hudson, P. K., Viggiano, A. A., Avallone, L. M., Hallar, A. G., Anderson, B. E., Sachse, G. W., Vay, S. A., Hunton, D. E., Ballenthin, J. O., and Miller, T. M.: Uptake of reactive nitrogen on cirrus cloud particles in the upper troposphere and lowermost stratosphere, Geophys. Res. Lett., 30, 1154, doi: 10.1029/2002GL016539, 2003.

Konopka, P.: Analytical Gaussian solutions for aniosotropic diffusion in a linear shear flow, J. Non-Equilib. Thermodyn., 20, 78-91, 1995.

Krämer, M., Schiller, C., Voigt, C., Schlager, H., and Popp, P. J.: A climatological view of $\mathrm{HNO}_{3}$ partitioning in cirrus clouds, Q. J. Roy. Meteorol. Soc., 134, 905-912, 2008.

Lawrence M. G., Rasch, P. J., von Kuhlmann, R., Williams, J., Fischer, H., de Reus, M., Lelieveld, J., Crutzen, P. J., Schultz M. Stier, P., Huntrieser, H., Heland, J., Stohl, A., Forster, C., Elbern, H., Jakobs H., and Dickerson, R. R.: Global chemical weather forecasts for field campaign planning: predictions and observations of large-scale features during MINOS, CONTRACE, and INDOEX, Atmos. Chem. Phys., 3, 267-289, doi:10.5194/acp-3-
267-2003, 2003.

Lawson, R. P., Heymsfield, A. J., Aulenbach, S. M., and Jensen, T. L.: Shapes, sizes and light scattering properties of ice crystals in cirrus and a persistent contrail during SUCCESS, Geophys. Res. Lett., 25(9), 1331-1334, doi:10.1029/98GL00241, 1998.

Lawson, R. P., OConnor, D., Zmarzly, P., Weaver, K., Baker, B., Mo, Q. and Jonsson, H.: The 2D-S (Stereo) Probe: Design and Preliminary Tests of a New Airborne, High-Speed, HighResolution Particle Imaging Probe, J. Atmos. Ocean. Technol., 23, 1462-1477, 2006.

Lawson, R. P., Jensen, E., Mitchell, D. L., Baker, B., Mo, Q., and Pilson, B.: Microphysical and radiative properties of tropical clouds investigated in TC4 and NAMMA, J. Geophys. Res., 115, D00J08, doi:10.1029/2009JD013017, 2010.

Lee, D. S., Fahey, D. W., Forster, P. M., Newton, P. J., Wit, R. C. N., Lim, L. L., Owen, B., and Sausen, R.: Aviation and global climate change in the 21st century, Atmos. Env., 43, 3520-3537, doi:10.1016/j.atmosenv.2009.04.024, 2009.

Lewellen, D. C. and Lewellen, W. S.: The effects of aircraft wake dynamics on contrail development, J. Atmos. Sci., 58, 390-406, 2001.

Locatelli, J. D. and Hobbs, P. V. : Fall speeds and masses of solid precipitation particles, J. Geophys. Res., 79, 2185-2197, 1974.

McFarquhar, G., Um, J., Freer, M., Baumgardner, D., Kok, G. L., and Mace, G.: Importance of small ice crystals to cirrus properties: Observations from the Tropical Warm Pool International Cloud Experiment (TWP-ICE), Geophys. Res. Let., 34, L13803, doi:10.1029/2007GL029865, 2007.

Meilinger, S. K., Kärcher, B., and Peter, Th.: Microphysics and heterogeneous chemistry in aircraft plumes - high sensitivity on local meteorology and atmospheric composition, Atmos. Chem. Phys., 5, 533-545, doi:10.5194/acp-5-533-2005, 2005.

Miake-Lye, R., Anderson, B., Cofer, W., Wallio, H., Nowicki, G., Ballenthin, J., Hunton, D., Knighton, W., Miller, T., Seeley, J., and Viggiano, A.: SOx oxidation and volatile aerosol in aircraft exhaust plumes depend on fuel sulfur content, Geophys. Res. Lett., 25, 1677-1680, 1998.

Minnis, P., Schumann, U., Doelling, D. R., Gierens, K., and Fahey, D. W.: Global distribution of contrail radiative forcing, Geophys. Res. Lett., 26, 1853-1856, 1999.

Minnis, P., Palikonda, R., Walter, B. J., Ayers, J. K., and Mannstein, H.: Contrail properties over the eastern North Pacific from AVHRR data, Meteorol. Z., 14, 515-523, 2005.

Neuman, J. A., Gao, R. S., Fahey, D. W., Holecek, J. C., Ridley, B. A., Walega, J. G., Grahek, F. E., Richard, E. C., McElroy, C. T., Thompson, T. L., Elkins, J. W., Moore, F. L., and Ray, E. A.: In situ measurements of $\mathrm{HNO}_{3}, \mathrm{NO}_{\mathrm{y}}, \mathrm{NO}$, and $\mathrm{O}_{3}$ in the lower stratosphere and upper troposphere, Atmos. Environ., 35, 5789-5797, 2001.

Penner, J. E., Lister, D. H., Griggs, D. J., Dokken, D. J., and McFarland, M.: Aviation and the global atmosphere - A special report of IPCC working groups I and III. Intergovernmental Panel on Climate Change, Cambridge University Press, 365 pp., 1999.

M. Poellot, Arnott, W., and Hallett, J.: In situ observations of contrail microphysics and implications for their radiative impact, J. Geophys. Res., 104(D10), 12077-12084, doi:10.1029/1999JD900109, 1999.

Popp, P. J., Gao, R. S., Marcy, T. P., Fahey, D. W., Hudson, P. K., Thompson, T. L., Kärcher, B., Ridley, B. A., Weinheimer, A. J., 
Knapp, D. J., Montzka, D. D., Baumgardner, D., Garrett, T. J., Weinstock, E. M., Smith, J. B., Sayres, D. S., Pittman, J. V., Dhaniyala, S., Bui, T. P., and Mahoney, M. J.: Nitric acid uptake on subtropical cirrus cloud particles, J. Geophys. Res., 109, D06302, doi:10.1029/2003JD004255, 2004.

Schäuble, D., Voigt, C., Kärcher, B., Stock, P., Schlager, H., Krämer, M., Schiller, C., Bauer, R., Spelten, N., de Reus, M., Szakall, M., Borrmann, S., Weers, U. and Peter, T.: Airborne measurements of the nitric acid partitioning in persistent contrails, Atmos. Chem. Phys., 9, 14165-14187, doi:10.5194/acp-914165-2009, 2009.

Schiller, C., Krämer, M., Afchine, A., Spelten, N., and Sitnikov, N.: Ice water content of Arctic, midlatitude, and tropical cirrus, J. Geophys. Res., 113, D24208, doi:10.1029/2008JD010342, 2008.

Schlager, H., Konopka, P., Schulte, P., Schumann, U., Ziereis, H., Arnold, F., Klemm, M., Hagen, D., Whitefield, P., and Ovarlez, J.: In situ observations of air traffic emission signatures in the North Atlantic flight corridor, J. Geophys. Res., 102(D9), 1073910750, doi:10.1029/96JD03748, 1997.

Schlager, H., Schulte, P., Flatoy, F., Slemr, F., van Velthoven, P., Ziereis, H., and Schuman, U.: Regional nitric oxide enhancements in the North Atlantic Flight corridor observed and modelled during POLINAT 2 - a case study, Geophys. Res. Lett., 26(20), 3061-3064, 1999.

Schmale, J., Schneider, J., Jurkat, T., Voigt, C., Kalesse, H., Rautenhaus, M., Lichtenstern, M., Schlager, H., Ancellet, G., Arnold, F., Gerding, M., Mattis, I., Wendisch, M., and Borrmann, S.: Aerosol layers from the 2008 eruptions of Mt. Okmok and Mt. Kasatochi: In-situ UT/LS measurements of sulfate and organics over Europe, J. Geophys. Res., 115, D00L07, doi:10.1029/2009JD013628, 2010.

Schmitt, A. and Brunner, B.: Emissions from aviation and their development over time, in: Pollutants from air traffic results of atmospheric research 1992-1997, Final Report on the BMBF Verbundprogramm: Schadstoffe in der Luftfahrt, Tech. report, DLR-Mitteilung 97-04, 1-301, 1997.

Schröder, F., Kärcher, B., Duroure, C., Ström, J., Petzold, A., Gayet, J. F., Strauss, B., Wendling, P., and Borrmann, S.: On the transition of contrails into cirrus clouds, J. Atmos. Sci., 57, 464-480, 2000 .

Schulte, P., Schlager, H., Ziereis, H., Schumann, U., Baughcum, S. L., and Deidewig, F.: $\mathrm{NO}_{\mathrm{x}}$ emission indices of subsonic longrange jet aircraft at cruise altitude: In situ measurements and predictions, J. Geophys. Res., 102 21431-21442, 1997.

Schumann, U., and Konopka, P.: A simple estimate of the concentration beld in a flight corridor, in: Impact of Emissions from Aircraft and Spacecraft upon the Atmosphere. Proc. of an Intern. Sci. Colloquium, Köln (Cologne), Germany, 18-20 April 1994, edited by: Schumann, U. and Wurzel, D., DLR-Mitt. 9406, Köln, Germany, 354-359, 1994.

Schumann, U., Konopka, P., Baumann, R., Busen, R., Gerz, T., Schlager, H., Schulte, P., and Volkert, H.: Estimate of diffusion parameters of aircraft exhaust plumes near the tropopause from nitric oxide and turbulence measurements, J. Geophys. Res., 100, 14147-14162, 1995.

Schumann, U.: On conditions for contrail formation from aircraft exhaust, Met. Zeit., 5, 4(23), 395-414, 1996.

Schumann, U., Schlager, H., Arnold, F., Baumann, R., Haschberger, P., and Klemm, O.: Dilution of aircraft exhaust plumes at cruise altitudes, Atmos. Environ., 32, 3097-3103, 1998.

Schumann, U., Busen, R., and Plohr, M.: Experimental test of the influence of propulsion efficiency on contrail formation, J. Aircraft, 37, 1083-1087, 2000.

Schumann, U., Schlager, H., Arnold, F., Ovarlez, J., Kelder, H., Hov, O., Hayman, G., Isaksen, I., Staehelin, J., and Whitefield, P.: Pollution from aircraft emissions in the North Atlantic flight corridor: Overview on the POLINAT projects, J. Geophys. Res. 105(D3), 3605-3631, 2000.

Schumann, U.: Contrail cirrus, Cirrus, edited by: Lynch, D. K., Sassen, K., Star, D., Stephens, G., Oxford University Press, New York, USA, 2002.

Schumann, U.: A contrail cirrus prediction tool, Proceedings of the 2nd International Conference on Transport, Atmosphere and Climate (TAC-2), Aachen, DE, and Maastricht, NL, 22-25 June 2009, DLR-Forschungsbericht No. 2010-10, Cologne, Germany, ISSN 1434-8454, 69-74, 2010.

Schumann, U., Mayer, B., Graf, K., Mannstein, H., and Meerkoetter, R.: A parametric radiative forcing model for cirrus and contrail cirrus, ESA Atmospheric Science Conference, Special Publication SP-676, Barcelona, Spain, 6 pp., 7-11 September 2009.

Starik, A., Savel'ev, A., Titova, N., and Schumann, U.: Modeling of sulfur gases and chemiions in aircraft engines, Aerospace Sci. Tech., 6, 63-81, 2002.

Sussmann, R. and Gierens, K.: Lidar and numerical studies on the different evolution of vortex pair and secondary wake in young contrails, J. Geophys. Res., 104, 2131-2142, 1999.

Solomon, S., Portmann, R. W., Garcia, R. R., Randel, W., Wu, F., Nagatani, R., Gleason, J., Thomason, L., Poole, L. R., and McCormick, M. P.: Ozone depletion at mid-latitudes: Coupling of volcanic aerosols and temperature variability to anthropogenic chlorine, Geophys. Res. Lett. 25, 1871-1874, 1998.

Somnitz, H., Gleitsmann, G. G., and Zellner, R.: Novel rates of $\mathrm{OH}$ induced sulfur oxidation. Implications to the plume chemistry of jet aircraft, Met. Zeitschrift, 14, 459-464, 2005.

Speidel, M., Nau, R., Arnold, F., Schlager, H., and Stohl, A.: Sulfur dioxide measurements in the lower, middle and upper troposphere: Deployment of an aircraft-based chemical ionization mass spectrometer with permanent in-flight calibration, Atmos. Environ., 41, 2427-2437, doi:10.1016/j.atmosenv.2006.07.047, 2007.

Stohl, A., Haimberger, L., Scheele, M. P., and Wernli, H.: An intercomparison of results from three trajectory models, Meteorol. Appl., 8, 127-135, 2001.

Sussmann, R. and Gierens, K.: Lidar and numerical studies on the different evolution of vortex pair and secondary wake in young contrails, J. Geophys. Res., 104, 2131-2142, 1999.

Textor, C., Graf, H. F., Herzog, M. and Oberhuber, J. M.: Injection of gases into the stratosphere by explosive volcanic eruptions, J. Geophys. Res., 108, 4606, doi:10.1029/2002JD002987, 2003.

Tremmel, H. G., Schlager, H., Konopka, P., Schulte, P., Arnold, F., Klemm, M., and Droste-Franke, B.: Observations and model calculations of jet aircraft exhaust products at cruise altitude and inferred initial OH emissions, J. Geophys. Res., 103, 1080310816, 1998.

Tompkins, A., Gierens, K., and Rädel, G.: Ice supersaturation in the ECMWF Integrated Forecast System, Q. J. R. Meteorol. Soc., 133, 53-63, doi:10.1002/qj.14, 2007.

Unterstrasser, S., Gierens, K., and Spichtinger, P.: The evolution 
of contrail microphysics in the vortex phase, Meteorol. Z., 17, 145-156, 2008.

Unterstrasser, S. and Gierens, K.: Numerical simulations of contrail-to-cirrus transition - Part 1: An extensive parametric study, Atmos. Chem. Phys., 10, 2017-2036, doi:10.5194/acp-102017-2010, 2010.

Voigt, C., Schlager, H., Luo, B., Drnbrack , A., Roiger, A., Stock, P., Curtius, J., Vssing, H., Borrmann, S., Konopka, P., Schiller, C., Shur, G., Peter, T.: Nitric Acid Trihydrate (NAT) formation at low NAT supersaturation in Polar Stratospheric Clouds, Atmos. Chem. Phys., 5, 11371-1380, doi:10.5194/acp-5-113712005, 2005.

Voigt, C., Schlager, H., Ziereis, H., Kärcher, B., Luo, B. P., Schiller, C., Krämer, M., Popp, P. J., Irie, H., and Kondo, Y.: Nitric acid in cirrus clouds, Geophys. Res. Lett., 33, L05803, doi:10.1029/ 2005GL025159, 2006.

Voigt, C., Kärcher, B., Schlager, H., Schiller, C., Krämer, M., de Reus, M., Vössing, H., Borrmann, S., and Mitev, V.: In-situ observations and modeling of small nitric acid-containing ice crystals, Atmos. Chem. Phys., 7, 3373-3383, doi:10.5194/acp7-3373-2007, 2007.

Voigt, C., Schlager, H., Roiger, A., Stenke, A., de Reus, M., Borrmann, S., Jensen, E., Schiller, C., Konopka, P., and Sitnikov, N.: Detection of reactive nitrogen containing particles in the tropopause region - evidence for a tropical nitric acid trihydrate (NAT) belt, Atmos. Chem. Phys., 8, 7421-7430, doi:10.5194/acp-8-7421-2008, 2008.

Wendisch, M., Mller, D., Schell, D., and Heintzenberg, J.: An airborne spectral albedometer with active horizontal stabilization, J. Atmos. Oceanic Technol., 18, 1856-1866, 2001.
WMO (World Meteorological Organization): Scientific Assessment of Ozone Depletion: 2006, Global Ozone Monitoring Project Report No. 50, p. 572, Geneva, Switzerland, 2007.

Wood, E., Herndon, S., Timko, M., Yelvington, P., and Miake-Lye, R.: Speciation and chemical evolution of nitrogen oxides in aircraft exhaust near airports, Environ. Sci. Tech., 42, 1884-1891, 2008.

Wormhoudt, J., Herndon, S., Yelvington, P., Miake-Lye, R., and Wey, C.: Nitrogen oxide (NO/NO2/HONO) emissions measurements in aircraft exhausts, J. Prop. Power, 23, 906-911, 2007.

Wernli, H. and Davies, H. C.: A Lagrangian-based analysis of extratropical cyclones. Part I: The method and some applications, Q. J. Roy. Meteor. Soc., 123, 467-489, 1997.

Ziereis, H., Schlager, H., Schulte, P., Köhler, I., Marquardt, R. and Feigl, C.: In situ measurements of the $\mathrm{NO}_{\mathrm{x}}$ distribution and variability over the eastern North Atlantic, J. Geophys. Res., 104(D13), 16021-16032, 1999.

Ziereis, H., Minikin, A., Schlager, H., Gayet, J. F., Auriol, F., Stock, P., Baehr, J., Petzold, A., Schumann, U., Weinheimer, A., Ridley, B., and Ström, J.: Uptake of reactive nitrogen on cirrus cloud particles during INCA, Geophys. Res. Lett., 31, L05115, doi: 10.1029/2003GL018794, 2004.

Zöger, M., Afchine, A., Eicke, N., Gerhards, M. T., Klein, E., McKenna, D. S., Mörschel, U., Schmidt, U., Tan, V., Tuitjer, F., Woyke, T., and Schiller, C.: Fast in situ stratospheric hygrometers: A new family of balloon-borne and airborne Lyman- $\alpha$ photofragment fluorescence hygrometers, J. Geophys. Res., 104, 1807-1816, 1999. 